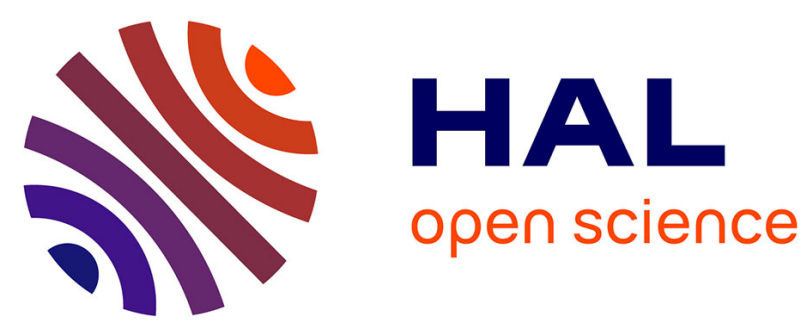

\title{
Zn-Al layered double hydroxide-based nanocomposite functionalized with an octahedral molybdenum cluster exhibiting prominent photoactive and oxidation properties
}

T.K.N. Nguyen, L.Y. Matsui, Naoto Shirahata, N. Dumait, Stéphane Cordier, Fabien Grasset, N. Ohashi, Tetsuo Uchikoshi

\section{To cite this version:}

T.K.N. Nguyen, L.Y. Matsui, Naoto Shirahata, N. Dumait, Stéphane Cordier, et al.. Zn-Al layered double hydroxide-based nanocomposite functionalized with an octahedral molybdenum cluster exhibiting prominent photoactive and oxidation properties. Applied Clay Science, 2020, 196, pp.105765. 10.1016/j.clay.2020.105765 . hal-02931981

\section{HAL Id: hal-02931981 \\ https://hal.science/hal-02931981}

Submitted on 9 Sep 2020

HAL is a multi-disciplinary open access archive for the deposit and dissemination of scientific research documents, whether they are published or not. The documents may come from teaching and research institutions in France or abroad, or from public or private research centers.
L'archive ouverte pluridisciplinaire HAL, est destinée au dépôt et à la diffusion de documents scientifiques de niveau recherche, publiés ou non, émanant des établissements d'enseignement et de recherche français ou étrangers, des laboratoires publics ou privés. 
1 Zn-Al layered double hydroxide-based nanocomposite functionalized with an

2 octahedral molybdenum cluster exhibiting prominent photoactive and oxidation

$3 \quad$ properties

4

$5 \quad$ Ngan Thi Kim Nguyen ${ }^{1,2}$, Yoshio Matsui ${ }^{1}$, Naoto Shirahata ${ }^{3}$, Noée Dumait ${ }^{4}$, Stéphane

6 Cordier $^{4}$, Fabien Grasset ${ }^{1,2,4}$, Naoki Ohashi ${ }^{1,2}$ and Tetsuo Uchikoshi ${ }^{1,2^{*}}$

7

8 1) Research Center for Functional Materials, National Institute for Materials

9 Science (NIMS), 1-2-1 Sengen, Tsukuba, Ibaraki 305-0047, Japan

2) CNRS-Saint-Gobain-NIMS, UMI 3629, Laboratory for Innovative Key

Materials and Structures (LINK), National Institute for Materials Science, 1-1

Namiki, Tsukuba, Ibaraki 305-0044, Japan

3) Research Center for Materials Nanoarchitectonics (MANA), National Institute for Materials Science (NIMS), 1-1 Namiki, Tsukuba 305-0044, and Japan

4) Univ. Rennes, ENSCR, INSA Rennes, CNRS, ISCR (Institut des Sciences

Chimiques de Rennes) - UMR 6226, F-35000 Rennes, France

18 Corresponding author:

19 Tetsuo UCHIKOSHI

20 Full postal address: Research Center for Functional Materials, National Institute for

21 Materials Science (NIMS), 1-2-1 Sengen, Tsukuba, Ibaraki 305-0047, Japan

22 Telephone: +81-29-859-2460 / Fax: $+81-29-859-2401$

23 E-Mail address: UCHIKOSHI.Tetsuo@ nims.go.jp 
Thi Kim Ngan NGUYEN

Full postal address: Research Center for Functional Materials, National Institute for Materials Science (NIMS), 1-2-1 Sengen, Tsukuba, Ibaraki 305-0047, Japan E-Mail address: NGUYEN.Thikimngan@nims.go.jp

Abstract

A new layered double hydroxide (LDH)-based nanocomposite functionalized with an octahedral molybdenum atom cluster (MC) exhibiting prominent photoactive and oxidation properties was synthesized. Zn-Al LDH and Zn-Al LDH intercalated dodecyl sulfate compounds (abbreviated as LDH-1 and LDH-2 respectively) were prepared by the co-precipitation method in an aqueous solution. The MCs were simply introduced into the LDH-2 by an anion exchangeable method in dimethylformamide under ambient conditions. The extension of the basal spacing of the LDH-1 from $0.9 \mathrm{~nm}$ to about $5 \mathrm{~nm}$ by intercalating dodecyl sulfate and $\mathrm{Mo}_{6}$ cluster was confirmed by several complementary technics. The octahedral structure of the $\mathrm{Mo}_{6}$ cluster was retained after the modification process in an organic dispersing medium that was confirmed by ultraviolet-visible absorption and photoluminescence experiments. The possible chemical bonding between the $\left[\mathrm{Mo}_{6} \mathrm{Cl}_{8}^{\mathrm{i}} \mathrm{Cl}_{6-\mathrm{x}-\mathrm{y}}^{\mathrm{a}}\left(\mathrm{H}_{2} \mathrm{O}\right)_{\mathrm{x}}(\mathrm{OH})_{\mathrm{y}}^{\mathrm{a}}\right]^{\mathrm{x}-2}(\mathrm{x}=0,1$ or 2 and $\mathrm{y}=0$, $1,2,3 ; \mathrm{x}+\mathrm{y}=3$ ) clusters and LDH-2 was suggested on the basis of by X-ray photoelectron spectroscopy. The excellent photoactive and oxidation performance of the $\mathrm{Mo}_{6}$ cluster on the methylene blue degradation in an aqueous solution was determined in the dark, under UV light $(\lambda=370 \mathrm{~nm})$ or with the existence of $\mathrm{H}_{2} \mathrm{O}_{2}$. The combination of the LDH-2 with a high absorbability and recyclability and the $\mathrm{Mo}_{6}$ cluster will be a 
promising candidate as a heterogenized homogeneous catalyst for removing organic pollutants.

KEYWORDS: molybdenum, octahedral cluster, outer surface functionalization, layered double hydroxide, photochemistry, pollutant degradation

\section{INTRODUCTION}

Among the various wastewater treatment techniques, the adsorption has been proposed as one of the best methods due to its inexpensiveness, universal nature, and ease of operation. Many studies have paid attention to determining new functional and largescale productive materials for removing organic pollutants by adsorption combined with photocatalytic degradation [1]. This approach becomes an important pathway for pharmaceutical contaminant removal that attracts huge interests of the studies based on $\mathrm{TiO}_{2}, \mathrm{ZnO}$, or graphene-functionalized materials [2, 3]. Besides, layered double hydroxides (LDH) are well known as important compounds due to their interlayer anion exchangeability and potential material for industrial-scale applications such that their fundamental understanding in heterogeneous catalysis, water treatment, and drug delivery is developed [4-5]. $\mathrm{LDH}$ with the general formula of $\left[\mathrm{M}^{2+}{ }_{1-}\right.$ $\left.{ }_{\mathrm{x}} \mathrm{M}^{3+}{ }_{\mathrm{x}}(\mathrm{OH})_{2}\right]^{\mathrm{x}+}\left[\mathrm{A}^{\mathrm{n}-}\right]_{\mathrm{x} / \mathrm{n}} \cdot \mathrm{mH}_{2} \mathrm{O}\left(\mathrm{x}\right.$ as the molar ratio $\mathrm{M}^{2+} /\left(\mathrm{M}^{2+}+\mathrm{M}^{3+}\right)$ in the range $0.2-$ 0.33 ) is composed of the divalent and trivalent metals occupying at the octahedral center [6]. The positive charges on the metal hydroxide layers are generated by the exchange of the divalent metals $(\mathrm{Cu}, \mathrm{Zn}, \mathrm{Co}, \mathrm{Mg}, \mathrm{Cr} . .$.$) by the trivalent metals (\mathrm{Al}, \mathrm{Fe}, \mathrm{Tb} . .$.$) and$ it is neutralized by negatively exchangeable organic or inorganic ions $\left(\mathrm{A}=\mathrm{NO}_{3}{ }^{-}, \mathrm{CO}_{3}{ }^{2-}\right.$, $\mathrm{SO}_{4}{ }^{2-}, \mathrm{F}^{-}, \mathrm{Cl}^{-}$or alkyl anions...) accompanied by the absorption of the interlayer water 
molecules [7-12]. The remarkable advantages of the LDH are made of relatively inexpensive and safe elements, highly adjustable, and easily synthesized that becomes good advantages for industrial-scale applications. The physicochemical characteristics could be controlled by the flexible exchange of the chemical components of the metal hydroxide-based layer or the functionalization of the exchangeable interlayer ions.

Based on the host lamellar structure and ionic exchangeable possibility, LDH has been widely studied in applicable fields such as absorbents [12], prominent photoactive catalysts $[13,14]$, energy conversion and storage [15], and drug delivery systems [1618], as a result of the modification of the trivalent metal. Moreover, the efficiency of the catalytic characteristics of the LDH has been highlighted to study the organic reactions such as aldol condensation [19], ethanol electro-oxidation [20], and dinitrogen fixation [21]. Most of the cases depend on the catalytic possibility of the functional groups existing between the ionic metal hydroxide layers. Particularly, single-atom $\mathrm{Au}-$ intercalated $\mathrm{NiFe} \mathrm{LDH}$, Ce-doped $\mathrm{MgAl} \mathrm{LDH}$ functionalized $\mathrm{Au}$ nanoparticles, or polyoxometalate-intercalated LDH have revealed the optimal achievements for catalytic applications [22-24].

The improvement of the typical physicochemical characteristics or enhancement of the active sites by adjusting the interlayer trivalent or divalent metals of the LDH as well as exchanging a functionalized interlayer component was widely investigated. However, the challenge to figure out a suitable synthesis depends on the intrinsic property and size of the functional-controlling substances. In this study, the $\mathrm{Cs}_{2} \mathrm{Mo}_{6} \mathrm{Cl}_{14}(\mathrm{CMC})$ clusters compound, with excellent redox and optical properties, has been selected as a catalytic functionalized group to combine with the LDH. As is known, the basic concept of metal atom cluster (MC) was first introduced by F. A. Cotton in 1964 to define a finite group 
of the metal atoms (two or more) that are held together by metal-metal bonds and surrounded by other nonmetal ligands [25]. Typically, the octahedral $\mathrm{MC}\left(\mathrm{M}_{6}\right)$ composed of the $\left\{\mathrm{M}_{6} \mathrm{~L}_{8}^{\mathrm{i}}\right\}^{4+}(\mathrm{M}=\mathrm{Mo}, \mathrm{W}, \mathrm{Re})$ metallic cores $\left(\mathrm{L}^{\mathrm{i}}=\right.$ inner ligand $)$ coordinating with apical ligands $\left(\mathrm{L}^{\mathrm{a}}=\mathrm{Cl}, \mathrm{Br}\right.$, I or $\left.\mathrm{OCOC}_{\mathrm{n}} \mathrm{F}_{2 \mathrm{n}+1}\right)$ exhibits strong absorption in both the ultraviolet (UV) and visible light ranges, resulting in a prominent luminescent emission within the deep red/near-infrared (NIR) region [26-29]. In the reduced form, the valence electron concentration (VEC) is equal to 24 electrons per the $\left[\mathrm{M}_{6} \mathrm{~L}_{8}^{\mathrm{i}} \mathrm{L}_{6}^{\mathrm{a}}\right]^{2-}$ cluster unit that visibly displays a redox characteristic for the catalyst application [30-32]. As previously reported, the excitation state of MC produces singlet oxygen $\left({ }^{1} \mathrm{O}_{2}\right)$ with a strong catalytic activity for the photoreduction applications has been investigated [33]. However, the $\mathrm{Mo}_{6}$ cluster in the bulk powder state is limited in the applicability as well. Graphene oxide or h-BN are ones of the excellent candidates to enhance the photocatalytic applicability of the $\mathrm{Mo}_{6}$ cluster has a proven highly catalytic efficiency for the hydrogen production from water [34], water purification [35], synthesis of dimethyl carbonate from $\mathrm{CO}_{2}$ and methanol [36] or photoreduction of carbon dioxide into methanol [37]. A remarkable study has been progressing to simultaneously combine the gold nanoparticles and the $\mathrm{Mo}_{6}$ cluster on the graphene oxide resulting in an excellent photoactive possibility for the degradation of rhodamine B under visible light irradiation [38]. A few studies have continued to determine efficient supporting materials for the catalytic-characterized $\mathrm{MC}$ with the expectation to fabricate the heterogeneous nanostructured composite for photovoltaic, nanobiotechnology, or energy-saving fields [27, 28].

The goal of this study is to focus on the photoactive and oxidation properties of the MC on dye degradation after combined with an LDH neutral supporting material with only 
high absorbability and recyclability. Indeed, among LDH, Zn/Al LDH (abbreviated as LDH-1) exists a weak basic catalyst, and $\mathrm{Zn}$ also was the limiting species for the photocatalytic reaction [39]. It was almost used as an efficient absorbent and/or support for multifunctional catalysts. In this work, the new nanocomposite (abbreviated as $\mathrm{Mo}_{6} @ \mathrm{LDH}-2$ ) was prepared by the delamination of $\mathrm{Zn}_{2} \mathrm{Al}$ LDH co-intercalated dodecyl sulfate (abbreviated as LDH-2) in dimethylformamide and then introducing the assynthesized $\left[\mathrm{Mo}_{6} \mathrm{Cl}_{8}^{\mathrm{i}} \mathrm{Cl}_{6}^{\mathrm{a}}\right]^{2-}$ cluster units. The initial octahedral structure of the $\mathrm{Mo}_{6}$ cluster was not modified after incorporation into the $\mathrm{LDH}$, as confirmed by the optical properties. The Mo-O-Al/Zn chemical bonding between the Mo atoms of the $\left\{\mathrm{Mo}_{6} \mathrm{Cl}_{8}^{\mathrm{i}}\right\}^{4+}$ anion cluster core and the LDH was validated. The new Mo 6 @DH-2 nanocomposites were successfully fabricated by a quick, cheap, and reproducible method with high and stable efficiency of the $\mathrm{Mo}_{6}$ cluster units. Moreover, we have demonstrated the catalytic activity of the $\mathrm{Mo}_{6}$ cluster anion intercalated in the $\mathrm{LDH}$ on the methylene blue.

\section{MATERIALS AND METHODS}

\subsection{Materials}

The $\mathrm{Zn}\left(\mathrm{NO}_{3}\right)_{2} \cdot 6 \mathrm{H}_{2} \mathrm{O}(99 \%)$ and $\mathrm{Al}\left(\mathrm{NO}_{3}\right)_{3} \cdot 9 \mathrm{H}_{2} \mathrm{O}(98 \%, \mathrm{pH}=2 \sim 4)$ were supplied from

137 Chameleon Reagent. Sodium n-dodecyl sulfate $\left(\mathrm{CH}_{3}\left(\mathrm{CH}_{2}\right)_{10} \mathrm{CH}_{2} \mathrm{OSO}_{3} \mathrm{Na}\right)$ was purchased from the Kanto Chemical Company. The sodium hydroxide ( $\mathrm{NaOH}, 5 \mathrm{~mol} / \mathrm{L})$ was purchased from Nacalai Tesque. All chemicals were used without purification. The

140 deionized water with the conductance of $0.5 .10^{-4} \mathrm{~S} / \mathrm{m}$ was obtained using Water 141 Purifiers WG710 equipment at $25^{\circ} \mathrm{C}$. 
Preparation of $\mathrm{LDH}-1$ and $\mathrm{LDH}-2$

145 LDH-1 and LDH-2 were prepared by the co-precipitation method with the $\mathrm{Zn}$ and $\mathrm{Al}$

146 ratio of about 2 [7, 40]. Fixed amounts of the $\mathrm{Zn}\left(\mathrm{NO}_{3}\right)_{2} \cdot 6 \mathrm{H}_{2} \mathrm{O}(0.02 \mathrm{~mol})$ and $147 \mathrm{Al}\left(\mathrm{NO}_{3}\right)_{3} \cdot 9 \mathrm{H}_{2} \mathrm{O}(0.01 \mathrm{~mol})$ salts were simultaneously dissolved in $50 \mathrm{ml}$ of deionized 148 water and agitated by a magnetic stirrer for $1 \mathrm{~h}$ to obtain a homogeneous solution. 149 Similarly, the transparent mixture solution containing the $\mathrm{Zn}\left(\mathrm{NO}_{3}\right)_{2} \cdot 6 \mathrm{H}_{2} \mathrm{O}(0.02 \mathrm{~mol})$, $150 \mathrm{Al}\left(\mathrm{NO}_{3}\right)_{3} \cdot 9 \mathrm{H}_{2} \mathrm{O}(0.01 \mathrm{~mol})$ and sodium dodecyl sulfate (SDS) $(0.01 \mathrm{~mol})$ in $50 \mathrm{ml}$ of 151 deionized water was used for the preparation of the LDH-2. The aqueous solution of $152 \mathrm{NaOH}(5 \mathrm{M})$ was then used to titrate the mixed salt solution until the $\mathrm{pH}$ value reached 153 10. The solution was then agitated for $24 \mathrm{~h}$ at room temperature to increase the 154 crystallinity of the LDH. The precipitated product was purified by deionized water several times until the $\mathrm{pH}$ was about 7 . The collected solid powder was dried at $60^{\circ} \mathrm{C}$ for $24 \mathrm{~h}$ for further use.

The CMC cluster unit was prepared according to a procedure already reported that combined the use of solid-state and solution chemistries [41, 42]. LDH-1 or LDH-2 (0.3 g) was dispersed in $140 \mathrm{ml}$ of dimethylformamide (DMF) by ultrasonication for $1 \mathrm{~h}$.

162 The yellow CMC cluster powder $(0.06 \mathrm{~g})$ was similarly dissolved in $60 \mathrm{ml}$ of DMF 163 solution by ultrasonication. LDH-1 or LDH-2 and CMC cluster solutions were then mixed and continually agitated for $24 \mathrm{~h}$ to improve the intercalation. The yellowcolored product was separated and washed with DMF to eliminate the residual $\mathrm{Mo}_{6}$ 
cluster, then dried at $60^{\circ} \mathrm{C}$ for $24 \mathrm{~h}$ for further characterizations. The experimentally determined wt. \% concentration of the CMC cluster powder in the Mo 6 @LDH-1 and Mo $@$ LDH-2 nanocomposite was about 16.7 wt.\%.

\subsection{Catalytic test}

The catalytic activity of the LDH and $\mathrm{Mo}_{6} @ \mathrm{LDH}$ samples was characterized by measuring the degradation possibility of methylene blue (MB) in an aqueous solution. The difference in the catalytic activity and adsorption-desorption isotherm was evaluated through the tests for LDH-2 and Mo 6 @DH-2 (catalyst/MB = 20). The investigation was performed on the solution containing $20 \mathrm{mg}$ of a catalyst in $10 \mathrm{ml}$ of MB solution $(20 \mathrm{mg} / \mathrm{L})($ catalyst/MB $=100)$ at room temperature without or with i) the addition of the $\mathrm{H}_{2} \mathrm{O}_{2}$ solution (5\% in ethanol, Sanwa Chemical Co., Ltd.), ii) irradiation of ultraviolet (UV) light $(\lambda=370 \mathrm{~nm})$ or iii) in the presence of both $\mathrm{H}_{2} \mathrm{O}_{2} / \mathrm{UV}$ system. A source of the UV light was generated by a 300 W Xenon lamp (MAX-303, Asahi Spectra Co., Ltd.). The MB degradable efficiency of the filtered catalyst-mixed MB solution was confirmed by the UV-Vis absorption spectroscopy (V-650, Jasco). The $\mathrm{C} / \mathrm{C}_{\mathrm{o}}$ index was calculated based on the intensity ratio of the optical absorption peak at $664 \mathrm{~nm}$ of $\mathrm{MB}$ with and without the existence of the catalyst. The catalytic reaction rate and the effect of $\mathrm{H}_{2} \mathrm{O}_{2}$ concentration on the degradation reaction of $\mathrm{MB}$ with and without the UV light were investigated. For comparison, the catalytic test of the CMC cluster alone was also carried out at the same $\mathrm{Mo}_{6}$ cluster concentration $(16.7 \mathrm{wt} \%)$ in the $\mathrm{Mo}_{6} @ \mathrm{LDH}-2$ nanocomposite. 
The average hydrodynamic diameters and distribution of the LDH-2 and Mo $@$ LDH-2 powders in water were measured by an ultrafine particle analyzer (Nanotrac NPA151 Nanotrac ULTRA, Microtrac Inc., USA) incorporated the controlled reference method $(\mathrm{CRM})$ in a dynamic light scattering instrument. The crystalline layered structure of the samples was determined by powder X-ray diffraction (XRD) (SmartLab, RIGAKU, 40 $\mathrm{kV}$ and $30 \mathrm{~mA}$ ) in the $2 \theta$ angle range from $1^{\circ}$ to $50^{\circ}$ for the bulk powder at the scan speed of $1 /$ min with the $\mathrm{Cu} \mathrm{K \alpha}$ radiation $(\lambda=1.54 \AA)$. The optical absorbances of the powders were measured by UV-Vis-NIR spectroscopy (V570, Jasco Corp.) in the wavelength range of 220 to $2000 \mathrm{~nm}$ at the scan rate of $400 \mathrm{~nm} / \mathrm{min}$. Emission spectra of the powder were obtained by high-performance fluorescence spectroscopy (JASCO FP8500) connected to a Xenon lamp at the scan rate of $500 \mathrm{~nm} / \mathrm{min}$. The surface morphology and the elemental composition were analyzed by field emission scanning electron microscopy (FE-SEM, S4800, Hitachi High-Technologies Corp.) at $10 \mathrm{kV}$ coupled with an energy-dispersive X-ray (EDX) analysis device. High-resolution observations of the powder were performed by a high-resolution transmission electron microscopy (HRTEM) (JEOL JEM 2100F) equipped with an EDX analysis device. Inductively coupled plasma optical emission spectrometry (ICP-OES, Agilent 720-ES) coupled with ion-chromatography (Thermofisher Scientific ICS-1600) was used to verify the element concentration. The typical chemical vibrations of the samples were verified by Fourier transform infrared spectroscopy (FTIR) (Thermo scientific Nicolet 4700) in the wavenumber range from 4000 to $400 \mathrm{~cm}^{-1}$. The nitrogen adsorption isotherm according to the BET model of the LDH-2 and Mo $@$ @DH-2 nanoparticles was performed in saturated vapor pressure of about $100 \mathrm{kPa}$ at the temperature of $140^{\circ} \mathrm{C}$ 
214 (TGA) and differential thermal analysis (DTA) were carried out using a TG/DTA 6200

215

216

217 apparatus (SII, EXSTAR 6000, Hitachi, Japan) operated in an $\mathrm{N}_{2}$ atmosphere at the heating rate of $10 / \mathrm{min}$. The electron binding energy spectra within the CMC and $\mathrm{Mo}_{6} @ \mathrm{LDH}-\mathrm{Zn} / \mathrm{Al}$ were measured by X-ray photoelectron spectroscopy (XPS) (PHI Quantera SXM (ULVAC-PHI)) using Al K $\alpha$ radiation at $20 \mathrm{kV}$ and $5 \mathrm{~mA}$ and taken off the angle of $45^{\circ}$. All binding energies were calibrated concerning the $\mathrm{C} 1 \mathrm{~s}$ peak of the adventitious carbon at $285 \mathrm{eV}$.

\section{RESULTS AND DISCUSSION}

Figure 1a shows the powder XRD patterns of the as-synthesized LDH-1, Mo $@$ LDH-1, LDH-2, and Mo $@$ @LDH-2 powders, and the characteristic peaks are observed. The LDH-1 exhibits the typical characteristic of the LDH phase assigned to structure I. The characteristic diffraction peaks (indexation in bracket) are located at $2 \theta$ angles of $11.6^{\circ}$ (003), $23.4^{\circ}(006), 34.5^{\circ}(009)$ and $39^{\circ}(015), 46^{\circ}(018)$ corresponding to the basal planes as claimed in previous reports [43]. Besides, the remarkable patterns of the $\mathrm{ZnO}$ phase formed on the brucite-like sheets were also verified with the peaks at the $2 \theta$ angles of $32^{\circ}, 34^{\circ}$, and $36^{\circ}$ in this study [43]. In the case of Mo $@$ LDH-1, it shows the same lamellar structure with LDH-1 without the change in the XRD peak positions. The basal plane spacing value of the 003 planes calculated by Bragg's law for LDH-1 is about $0.9 \mathrm{~nm}$ which is too narrow to intercalate the CMC clusters with a size of $1.2 \mathrm{~nm}$ [42]. For this reason, the dodecyl sulfate (DS) anion was selected to expand the space of the metal hydroxide layers in LDH-1 to form LDH-2. The XRD result of LDH-2 illustrates that a new series of reflections of the (003), (006) and (009) planes of LDH-2 simultaneously appear at the lower $2 \theta$ angle assigned to structure II and the $\mathrm{d}_{003}$ spacing 
value increases from 0.9 to $2.7 \mathrm{~nm}$. In addition, $\mathrm{LDH}-2$ still retained the original layered structure as seen for structure I in LDH-1. This result confirmed the partial exchange of $\mathrm{NO}_{3}{ }^{-}$anions by the $2 \mathrm{~nm}$-sized dodecyl sulfate anions as seen in previous reports [43, 44]. Very interestingly, the intercalation in the CMC cluster causes a significant reduction of peak intensity assigned to structure II of LDH-2 as seen in the XRD pattern of $\mathrm{Mo}_{6} @ \mathrm{LDH}-2$. It could be suggested that a part of the DS intercalated LDH, which is mixed with the $\mathrm{Mo}_{6}$ cluster, becomes a poorly crystallized phase, or undergoes exfoliation. Good interaction between the DMF molecules and dodecyl sulfate anions is efficient to expand the basal space between the brucite-like layers of LDH-2 that assists in the movement and intercalation of the $\mathrm{Mo}_{6}$ cluster during the intercalation step. The average hydrodynamic diameters and distributions of LDH-2 and $\mathrm{Mo}_{6} @ \mathrm{LDH}-2$ in water are displayed in Figure S1. The average hydrodynamic diameter of LDH-2 reduces from $0.5980 \mu \mathrm{m}$ to $0.2815 \mu \mathrm{m}$ for $\mathrm{Mo}_{6} @ \mathrm{LDH}-2$ corresponding to the broader size distribution. This result is agreeable with the crystallinity reduction of the LDH phase as claimed in the XRD pattern, resulting in a partial exfoliation. The BET surface areas of LDH-2 of about $50.0 \mathrm{~m}^{2} / \mathrm{g}$ and $\mathrm{Mo}_{6} @ \mathrm{LDH}-2$ of about $20.4 \mathrm{~m}^{2} / \mathrm{g}$ were evaluated by the nitrogen adsorption isotherm (Fig. S2a). The shape of the nitrogen adsorption isotherm curves of LDH-2 and Mo $@$ @LDH-2 is almost similar to the characteristic of the LDH. That proves the retention of the layered structure of the LDH in $\mathrm{Mo}_{6} @ \mathrm{LDH}-2$ after the partial exfoliation as suggested in the XRD pattern. The decrease of the adsorbed volume agrees with the pore diameter distribution in Figure S2b which shows the significant reduction of the small pore size in the range below $20 \mathrm{~nm}$. The schematic representation of the process to fabricate the $\mathrm{LDH}$ and the possible structure of its nanocomposite based on the XRD pattern are illustrated in Figure $\mathbf{1 b .}$ 
The HRTEM image of Mo ${ }_{6} @$ LDH-2 shows black areas assigned to the aggregated Mo 6 cluster anion (Fig. 2a). In the beginning, the CMC cluster dissociates in the solvent to form the $\mathrm{Cs}^{+}$cations and $\left[\mathrm{Mo}_{6} \mathrm{Cl}_{8}^{\mathrm{i}} \mathrm{Cl}_{6}^{\mathrm{a}}{ }_{6}\right]^{2-}$ anions. Moreover, it is well known that the $\left[\mathrm{Mo}_{6} \mathrm{Cl}_{8}^{\mathrm{i}} \mathrm{Cl}_{6}^{\mathrm{a}}\right]^{2-}$ anion is able to quickly exchange apical $\mathrm{Cl}$ ligands by water molecules or hydroxyl anions to obtain $\left[\mathrm{Mo}_{6} \mathrm{Cl}_{8}^{\mathrm{i}} \mathrm{Cl}^{\mathrm{a}}{ }_{6-(\mathrm{x}+\mathrm{y})}\left(\mathrm{H}_{2} \mathrm{O}\right)^{\mathrm{a}}{ }_{\mathrm{x}}(\mathrm{OH})_{\mathrm{y}}^{\mathrm{a}}\right]^{\mathrm{x}-2}(\mathrm{x}+\mathrm{y} \leq 6)$ clusters [45]. Indeed, the interlayer galleries of LDH are containing water molecules and hydroxyl for balancing the positively charged surface, which can react with the apical $\mathrm{Cl}$ ligands. Following a theoretical suggestion, we can assume that only the $\mathrm{Mo}_{6}$ anion or neutral compound can adsorb or deposit on the positive metal hydroxide surface of the LDH, so in that case $\mathrm{x}=0$ or 1 and $\mathrm{y}=0$ to 5 .

The layer structure of $\mathrm{Mo}_{6} @ \mathrm{LDH}-2$ is confirmed in the STEM image and the calculation of the basal spacing distance of about $5 \mathrm{~nm}$ as seen in Figures $\mathbf{2 b}$ and $2 \mathbf{c}$. STEM-EDX mapping of the $\mathrm{Mo}_{6} @ \mathrm{LDH}-2$ nanocomposite confirms the existence of Mo and $\mathrm{Cl}$ atoms as presented in Figure $\mathbf{2 d}$.

In order to confirm the stability of the octahedral structure of the $\mathrm{Mo}_{6}$ cluster in Mo 6 LDH-2, the optical properties of the reflectance and the photoluminescence were evaluated. It could be seen that LDH-1 and LDH-2 show a high optical absorption below 400 nm while Mo $\mathrm{M}_{6} @ \mathrm{LDH}-2$ is composed of the adsorbing part of the $\mathrm{Mo}_{6}$ cluster below $400 \mathrm{~nm}$ and the LDH below $370 \mathrm{~nm}$ (Fig. 3a). This result confirms the retention of the octahedral $\mathrm{Mo}_{6}$ structure on the LDH. In Figure 3b, LDH-1 and LDH-2 normally possess no photoluminescence in the NIR range while the $\mathrm{Mo}_{6}$ cluster shows a strong emission at $700 \mathrm{~nm}$ in the deep red/NIR region. However, the photoluminescent intensity of the $\mathrm{Mo}_{6}$ cluster is not strong in the spectrum of $\mathrm{Mo}_{6} @ \mathrm{LDH}-2$, this is due to the significant change in the apical halogen ligand of the CMC cluster. As known, the 
photoluminescent property of the $\mathrm{Mo}_{6}$ cluster is decreased when the apical halogen ligands are replaced by $\mathrm{H}_{2} \mathrm{O}$ molecules or hydroxyl anion [32, 41, 45].

The chemical bonding of the prepared compounds was verified by FT-IR spectroscopy presented in Figure 4. In the FT-IR spectrum of LDH-1 appears a strong peak at 1385 $\mathrm{cm}^{-1}$ that indicates for the $\mathrm{NO}_{3}^{-}$linking existing in the basal spacing of the LDH. In addition, the vibrational bands for $\mathrm{Zn}-\mathrm{O}$ at $427 \mathrm{~cm}^{-1}, \mathrm{Zn}-\mathrm{OH}$ at $608 \mathrm{~cm}^{-1}$ of the brucitelike layers, $\mathrm{O}-\mathrm{H}$ bending at $1650 \mathrm{~cm}^{-1}$ and $\mathrm{O}-\mathrm{H}$ stretching at the broadband of $3450 \mathrm{~cm}^{-1}$ of the free inter-lamellar water molecules are observed. The FT-IR spectrum of LDH-2 shows the vibrational bands assigned to the dodecyl sulfate: i) $\mathrm{C}-\mathrm{H}$ stretching vibrational band of $\mathrm{CH}_{2}$ at $2928 \mathrm{~cm}^{-1}$ and $\mathrm{CH}_{3}$ at $2854 \mathrm{~cm}^{-1}$ from the alkyl chain and ii) asymmetric stretching vibrational band at $1220 \mathrm{~cm}^{-1}$ and symmetric stretching vibrational band at $1059 \mathrm{~cm}^{-1}$ originating from the $\mathrm{OSO}_{3}{ }^{-}$group [43]. The vibrational signal of $\mathrm{NO}_{3}{ }^{-}$at $1385 \mathrm{~cm}^{-1}$ in LDH-2 decreases after exchanged by DS anions. The FTIR spectrum of $\mathrm{Mo}_{6} @ \mathrm{LDH}-2$ would be composed of the vibrational band of the LDH-2 and $\mathrm{Mo}_{6}$ clusters. Following the typical band intensity for DS, the concentration of DS is obviously reduced by an exchange of the $\mathrm{Mo}_{6}$ cluster. It should be noted that new peaks appear at $1654 \mathrm{~cm}^{-1}$ that were properly related to the $\mathrm{O}-\mathrm{H}$ bending vibrational band of the $\mathrm{H}_{2} \mathrm{O}$ free molecules with strong hydrogen bonding [46] as recognized in the report of the $\left[\mathrm{Mo}_{6} \mathrm{Br}_{8}^{\mathrm{i}} \mathrm{Br}^{\mathrm{a}}{ }_{6}\right]^{2-}$ cluster [47]. From this result, the hydrogen bonding could be created between apical groups of the $\left[\mathrm{Mo}_{6} \mathrm{Cl}_{8}^{\mathrm{i}} \mathrm{Cl}_{6-(\mathrm{x}+\mathrm{y})}^{\mathrm{a}}\left(\mathrm{H}_{2} \mathrm{O}\right)^{\mathrm{a}}{ }_{\mathrm{x}}(\mathrm{OH})_{\mathrm{y}}^{\mathrm{a}}\right]^{\mathrm{x}-2}$ clusters and 306 the free interlayer-adsorbed water molecules in the LDH.

Figure 5 shows the TG, DTG, and DTA results of the LDH-1, LDH-2, and Mo @LDH- $_{6}$ 
thermogravimetric behavior (DTG) shows the mass loss with four steps in the temperature range of $50-200{ }^{\circ} \mathrm{C}, 200-300{ }^{\circ} \mathrm{C}, 300-500{ }^{\circ} \mathrm{C}$ and $500-800^{\circ} \mathrm{C}$ for $\mathrm{LDH}-1,50$ $150,150-250,250-400$ and $400-800^{\circ} \mathrm{C}$ for LDH-2, and 50-150, 150-320, 320-600 and $600-800^{\circ} \mathrm{C}$ for $\mathrm{Mo}_{6} @ \mathrm{LDH}-2$. The weight loss in the first step indicates the release of the interlayer water molecules adsorbed on the surface of the $\mathrm{Zn}^{2+} / \mathrm{Al}^{3+}$ ionic brucite-like layers. Dehydroxylation and thermal degradation of the counter anion is realized at the second decomposing step and, simultaneously, metal oxidation occurs with the dehydroxylation of the brucite-like layers. The complete dehydroxylation occurs in the temperature range of $500-800^{\circ} \mathrm{C}$ that destroys the brucite-like structure of the LDH. In the last step, all the counter anions, which are strongly adsorbed on the metal oxide crystallites, would be removed.

The DTA curves of LDH-2 almost display only an exothermic event because of the quick decomposition of the dodecyl sulfate during the beginning steps. In contrast, the DTA results of LDH-1 and $\mathrm{Mo}_{6} @ \mathrm{LDH}-2$ show a similar endothermic event in the second thermal decomposing step. In this step, the phase transformation starts to occur and accelerates the melting process to destroy the crystallinity of the brucite-like layers in the third decomposition step. In $\mathrm{Mo}_{6} @ \mathrm{LDH}-2$, the surfactant concentration was significantly reduced that did not affect the decomposition as seen in LDH-2. In the third and fourth degradation steps, the performance of the metal oxide from the dihydroxylation of the brucite-like layers also enhances the enthalpy of the thermal event that linearly increases the endothermic value [43]. Interestingly, in the third degradation step of the DTA curve of $\mathrm{Mo}_{6} @ \mathrm{LDH}-2$, a clearly enhanced endothermic peak appears at $450{ }^{\circ} \mathrm{C}$ due to the formation of molybdenum oxide caused by the destruction of the $\mathrm{Mo}_{6}$ octahedral structure. 
Figure 6a summarizes the XPS spectra of the CMC and $\mathrm{Mo}_{6} @ \mathrm{LDH}-2$. All the binding

335

336 energies were calibrated concerning the $\mathrm{C} 1 \mathrm{~s}$ peak of the adventitious carbon at $285 \mathrm{eV}$. The binding energies of the $\mathrm{Zn}, \mathrm{Al}, \mathrm{C}, \mathrm{O}, \mathrm{Cs}, \mathrm{Mo}, \mathrm{Cl}$, and $\mathrm{S}$ elements in the $\mathrm{CMC}$ and $\mathrm{Mo}_{6} @ \mathrm{LDH}-2$ powders are listed in Table S1. Interestingly, the Cs element was not found in $\mathrm{Mo}_{6} @ \mathrm{LDH}-2$, as presented in Figure 6a. As already explained, in the solvent, the $\mathrm{CMC}$ cluster dissociated to $2 \mathrm{Cs}^{+}$and $1\left[\mathrm{Mo}_{6} \mathrm{Cl}_{8}^{\mathrm{i}} \mathrm{Cl}_{6}^{\mathrm{a}}\right]^{2-}$ ions and the $\mathrm{Cs}^{+}$cation can be kept by the exchangeable anion adsorbed on the $\mathrm{LDH}$ or $\mathrm{Cl}$ - from $\mathrm{CMC}$, which was removed through the washing step. The binding energies of $\mathrm{Zn} 2 \mathrm{p}$ and $\mathrm{Al} 2 \mathrm{p}$ are respectively assigned by the two peaks at $1022.3 \mathrm{eV}\left(2 \mathrm{p}_{3 / 2}\right)$ and $1045.4 \mathrm{eV}\left(2 \mathrm{p}_{1 / 2}\right)$ and a peak of $74.7 \mathrm{eV}$ that agrees with a previous study [48]. The dodecyl sulfate component is confirmed by the appearance of the binding energy of the S2p at the peak of $169.1 \mathrm{eV}$. It is important to verify the difference in the binding energy of the Mo and $\mathrm{Cl}$ components in the $\mathrm{Mo}_{6}$ cluster after intercalated into the $\mathrm{LDH}$.

In Figure 6b, the Mo3d XPS spectrum of the CMC cluster shows peaks at $229.7 \mathrm{eV}$ $\left(3 \mathrm{~d}_{5 / 2}\right)$ and $232.8 \mathrm{eV}\left(3 \mathrm{~d}_{3 / 2}\right)$ assigned to the $\mathrm{Mo}^{2+}$ cation from the $\left[\mathrm{Mo}_{6} \mathrm{Cl}_{14}\right]^{2-}$ cluster [36]. In the XPS spectrum of Mo ${ }_{6} @$ LDH-2, the Mo3d binding energy is recognized by the peaks at $229.7 \mathrm{eV}\left(3 \mathrm{~d}_{5 / 2}\right)$ and $232.6 \mathrm{eV}\left(3 \mathrm{~d}_{3 / 2}\right)$ related to the $\mathrm{Mo}_{6}{ }^{-}$cluster $[49,50,51]$. Interestingly, one new peak at $234 \mathrm{eV}\left(3 \mathrm{~d}_{3 / 2}\right)$ indicating Mo-O appears in the Mo 6 @LH-2 compound. It could be proof for the interaction between the Mo atom from the $\mathrm{Mo}_{6}$ cluster and $\mathrm{O}$ atom from the hydrotalcite layers of the $\mathrm{LDH}$ to form the Mo-O-Zn or Mo-O-Al bonding. This behavior has been also claimed by Haiping Li et al. for the $\mathrm{Zn}(\mathrm{Al})-\mathrm{O}-\mathrm{Bi}(\mathrm{Mo})$ bonds between the $\mathrm{Bi}_{2} \mathrm{MoO}_{6}$ groups and $\mathrm{Zn} / \mathrm{Al}-\mathrm{LDH}$ [52]. Moreover, the O1s XPS spectrum of $\mathrm{Mo}_{6} @ \mathrm{LDH}-2$ shows a peak at $530.9 \mathrm{eV}$ indicating O-Mo bonding that was not confirmed in the XPS spectrum of the CMC cluster as 
expected (Tab. S1). In addition, the binding energy assigned to the O1s of CMC with a peak at $532.6 \mathrm{eV}$ that is verified for the freely absorbed water molecules (Tab. S1) while the binding energy of $\mathrm{O} 1 \mathrm{~s}$ of $\mathrm{Mo}_{6} @ \mathrm{LDH}-2$ is also characterized by a peak at $530.9 \mathrm{eV}$ which indicates the O-Zn, O-Al, or O-Mo bonding.

Similarly, the XPS spectrum of the CMC cluster for the Cl2p including three clear peaks at $198.3 \mathrm{eV}\left(2 \mathrm{p}_{3 / 2}\right), 200.4\left(2 \mathrm{p}_{3 / 2}\right)$, and $200.2\left(2 \mathrm{p}_{1 / 2}\right)$ while only one broad peak was observed for the Cl2p for $\mathrm{Mo}_{6} @ \mathrm{LDH}-2$ (Fig. 6c). To distinguish the inner and apical Cl ligands, the spectrum deconvolution of the $\mathrm{Cl} 2 \mathrm{p}$ region was performed for the XPS spectra of the $\mathrm{Cl} 2 \mathrm{p}$ of $\mathrm{CMC}$ cluster and $\mathrm{Mo}_{6} @ \mathrm{LDH}-2$, as listed in Table 2. The deconvolution spectrum of the $\mathrm{Cl} 2 \mathrm{p}$ region of the CMC cluster shows four peaks at 198.25, 199.85, 200.39 and $201.99 \mathrm{eV}$ that indicate $\mathrm{Cl}^{(\mathrm{a})} 2 \mathrm{p}_{3 / 2}, \mathrm{Cl}^{(\mathrm{a})} 2 \mathrm{p}_{1 / 2}, \mathrm{Cl}^{(\mathrm{i})} 2 \mathrm{p}_{3 / 2}$ and $\mathrm{Cl}^{(\mathrm{i})} 2 \mathrm{p}_{1 / 2}$, respectively (Fig. 6d and Tab. 1) [53]. For $\mathrm{Mo}_{6} @ \mathrm{LDH}-2$, the XPS deconvolution of the $\mathrm{Cl} 2 \mathrm{p}$ shows the same peaks at $198.25 \mathrm{eV}\left(\mathrm{Cl}^{(\mathrm{a})} 2 \mathrm{p}_{3 / 2}\right), 199.85 \mathrm{eV}$ $\left(\mathrm{Cl}^{(\mathrm{a})} 2 \mathrm{p}_{1 / 2}\right), 201.35\left(\mathrm{Cl}^{(\mathrm{i})} 2 \mathrm{p}_{3 / 2}\right)$, and $201.95 \mathrm{eV}\left(\mathrm{Cl}^{(\mathrm{i})} 2 \mathrm{p}_{1 / 2}\right)$ which are properly related to Mo-Cl of the $\left[\mathrm{Mo}_{6} \mathrm{Cl}_{8}^{\mathrm{i}} \mathrm{Cl}_{6}^{\mathrm{a}}\right]^{2-}$ anion (Fig. 6e). The ratio $\mathrm{Cl}^{(\mathrm{a})} 2 \mathrm{p} / \mathrm{Cl}^{(\mathrm{i})} 2 \mathrm{p}$ was experimentally calculated to be $5.8 / 8$ for the $\left[\mathrm{Mo}_{6} \mathrm{Cl}_{8}^{\mathrm{i}} \mathrm{Cl}_{6}^{\mathrm{a}}{ }_{6}\right]^{2-}$ anion in the $\mathrm{CMC}$ cluster and 3.6/8 for the $\left[\mathrm{Mo}_{6} \mathrm{Cl}_{8}^{\mathrm{i}} \mathrm{Cl}_{6-(\mathrm{x}+\mathrm{y})}^{\mathrm{a}}\left(\mathrm{H}_{2} \mathrm{O}\right)_{\mathrm{x}}^{\mathrm{a}}(\mathrm{OH})_{\mathrm{y}}^{\mathrm{a}}\right]^{\mathrm{x}-2}$ anion in $\mathrm{Mo}_{6} @ \mathrm{LDH}-2$. This deconvolution agrees with an analysis of the XPS spectra as mentioned in Table 1, following the average loss of at least three apical $\mathrm{Cl}$ ligands on the $\mathrm{Mo}_{6}$ anion in $\mathrm{Mo}_{6} @ \mathrm{LDH}-2$. All these results support for the possible chemical bonding between the $\left[\mathrm{Mo}_{6} \mathrm{Cl}_{8}^{\mathrm{i}} \mathrm{Cl}_{3}^{\mathrm{a}}{ }_{3}(\mathrm{OH})_{3}^{\mathrm{a}}\right]^{-2}$ or $\quad\left[\mathrm{Mo}_{6} \mathrm{Cl}_{8}{ }^{\mathrm{i}} \mathrm{Cl}_{3}^{\mathrm{a}}{ }_{3}\left(\mathrm{H}_{2} \mathrm{O}\right)^{\mathrm{a}}(\mathrm{OH})_{2}^{\mathrm{a}}\right]^{-1}$ anionic clusters or $\left[\mathrm{Mo}_{6} \mathrm{Cl}_{8}^{\mathrm{i}} \mathrm{Cl}^{\mathrm{a}}{ }_{3}\left(\mathrm{H}_{2} \mathrm{O}\right)^{\mathrm{a}}{ }_{2}(\mathrm{OH})^{\mathrm{a}}{ }_{1}\right]$ neutral cluster and the hydroxide of ZnAL LDH. Very interestingly, new peaks of the $\mathrm{Cl} 2 \mathrm{p}$ were noted in the deconvolution spectrum at 198.9 $\mathrm{eV}\left(2 \mathrm{p}_{3 / 2}\right)$ and $200.5 \mathrm{eV}\left(2 \mathrm{p}_{1 / 2}\right)$ that suggested the energy bonding of $\mathrm{Cl}$ with another 
metal ( $\mathrm{Zn}$ or $\mathrm{Al})$ [48]. It could be explained that the apical $\mathrm{Cl}^{-}$anions separated from the $\mathrm{Mo}_{6}$ cluster by exchange with the interlayer water molecules will directly adsorb on the positively charged hydrotalcite surface of the LDH. Aiming to clarify the quantitative analysis of the element components of $\mathrm{Mo}_{6} @ \mathrm{LDH}-2$, an ICP-OES analysis was performed that indicated the ratio of $\mathrm{Zn}, \mathrm{Al}$, and Mo atoms of about 1.96, 1.00, and 0.38. The Mo element definitely existed in the $\mathrm{Mo}_{6} @ \mathrm{LDH}-2$ at a significant concentration as well as confirmed in the STEM-EDX mapping image. The ratio between the $\mathrm{Cl}$ and Mo atoms in $\mathrm{Mo}_{6} @ \mathrm{LDH}-2$ indicated by ICP-OES analysis was 2.23 (the theoretical ratio is 2.33) which means almost all the original $\mathrm{Cl}$ (from ligands) still exist in the nanocomposite after treatment. This result suggests too that a part of the $\mathrm{Cl}^{-}$could be directly adsorbed on the LDH.

As known, the $\mathrm{H}_{2} \mathrm{O}_{2} / \mathrm{UV}$ or $\mathrm{H}_{2} \mathrm{O}_{2}$ /catalyst systems are widely used in advanced oxidation technology, one of the most environmentally friendly techniques to degrade pollutants [54]. In this study, the efficiency of the $\mathrm{MB}$ degradation caused by the $\mathrm{Mo}_{6}$ cluster deposited on LDH with and without UV and $\mathrm{H}_{2} \mathrm{O}_{2}$ or both as a radical generating source. Table $\mathbf{S 2}$ and Figure 7 present the change in the C/Co value that was calculated from the optical absorbance $(664 \mathrm{~nm})$ of the samples and blank illustrated in Figure S3. First, the evaluation of the MB adsorbing possibility of LDH-2 and Mo $@$ @LDH-2 was performed by stirring with $\mathrm{MB}$ aqueous solution (catalyst/MB $=20 / 1$ ) for $72 \mathrm{~h}$ in the dark (Fig. S3a). The intensity of the adsorbing peak at $664 \mathrm{~nm}$ assigned to $\mathrm{MB}$ significantly decreased by about 80 wt\% caused by Mo $@$ LDH-2, meanwhile, it is 66 wt $\%$ for LDH-2. Considering the BET surface area of LDH-2 of about $50.0 \mathrm{~g} / \mathrm{m}^{2}$ and Mo 6 @DH-2 of about 20.4 g/m² (Fig. S2), the adsorbing possibility of the Mo ${ }_{6} @ L D H-$ 2 should be lower than that of LDH-2. That means a part of the degraded MB is caused 
by the oxidation reaction of the $\mathrm{Mo}_{6}$ cluster. To clarify this phenomenon, the $\mathrm{Mo}_{6}$ cluster, LDH-2, Mo ${ }_{6} @ L D H-2$ powders were dispersed in the MB solution (catalyst/MB = 20/1) in the dark, with UV or $\mathrm{H}_{2} \mathrm{O}_{2}$ or both of them for $2 \mathrm{~h}$ (Fig. S3b and c). The calculated C/Co value of all samples was presented in Figure 7a and Table S2.

In Figure 7a, the decrease in the degraded MB concentration caused by the CMC cluster was recorded at $57 \%$ in the dark, at $98 \%$ with $\mathrm{UV}$ or $\mathrm{H}_{2} \mathrm{O}_{2}$ that proved strong oxidation and photoactive properties of the $\mathrm{Mo}_{6}$ cluster $[30,31]$. As a result, $\mathrm{Mo}_{6} @ \mathrm{LDH}-2$ also displays the MB degrading efficiency that is $71 \mathrm{wt} \%$ in dark and $96 \%$ with $\mathrm{H}_{2} \mathrm{O}_{2}$. Their $\mathrm{MB}$ degrading possibility slightly reduce in the irradiation of the UV light for the same catalyst. This result is proof for the advantage of the intercalation of the $\mathrm{Mo}_{6}$ cluster on the $\mathrm{LDH}$ in comparison with $\mathrm{LDH}$ that shows the degraded MB concentration at $54 \%$ in the dark and $65 \%$ with $\mathrm{H}_{2} \mathrm{O}_{2}$. Barras et al. reported the photocatalytic degradation of rhodamine $\mathrm{B}$ over $\left[\mathrm{Mo}_{6} \mathrm{Br}_{8}\left(\mathrm{~N}_{3}\right)_{6}\right]^{2-}$ cluster units under efficiency with the catalyst/MB ratio of $100 / 1$ even in the dark. For the first time, the combination of the $\mathrm{Mo}_{6}$ cluster and $\mathrm{H}_{2} \mathrm{O}_{2}$ was performed to test for the $\mathrm{Mo}_{6}$ cluster in the initial step of the MB degradation process.

Figure 7b and 7c illustrate the degradation rate and effect of the $\mathrm{H}_{2} \mathrm{O}_{2}$ concentration on 429 the catalytic activity of the $\mathrm{H}_{2} \mathrm{O}_{2} / \mathrm{Mo}_{6} @ \mathrm{LDH}-2$ with and without UV $(\lambda=370 \mathrm{~nm})$ light 
illumination as well as the change in the solution color as seen in Figure S4. The tested

431

432

433

434

435

436 suspensions were collected every 30 minutes from the original suspension for 210 minutes. The catalytic activity for the $\mathrm{MB}$ degradation decreases when the $\mathrm{H}_{2} \mathrm{O}_{2}$ concentration is increased. For this result, a suitable amount of $\mathrm{H}_{2} \mathrm{O}_{2}$ for the $20 \mathrm{mg}$ catalyst to obtain the optimal catalytic activity is recorded at $0.3 \mathrm{mM}$ in both cases with and without UV light illumination. The rate of the $\mathrm{MB}$ degradation by the $\mathrm{H}_{2} \mathrm{O}_{2}$ / $\mathrm{Mo}_{6} @ \mathrm{LDH}-2$ is also confirmed with the strong reduction of the MB concentration for the first 30 min that includes the absorption of $\mathrm{MB}$ on the surface of the $\mathrm{LDH}$. The $\mathrm{pH}$ increases, which is recorded during light irradiation, suggests the appearance of hydroxyl anions during the initial and propagating reactions. Moreover, the chemically component modification of the $\mathrm{Mo}_{6} @ \mathrm{LDH}-2$ nanocomposite after the reaction with $\mathrm{MB}$ in the presence of the $\mathrm{H}_{2} \mathrm{O}_{2}$ solution was measured by FTIR spectroscopy as seen in Figure S5. The vibrational band assigned to the $\mathrm{NO}_{3}{ }^{-}$group was significantly decreased accompanying a decrease in the $\mathrm{O}-\mathrm{H}$ vibrational band assigned to the free $\mathrm{H}_{2} \mathrm{O}$ molecules that prove the use of interlayer-absorbed $\mathrm{H}_{2} \mathrm{O}_{2}$ molecules for the degradation reaction of MB. Nevertheless, the XRD patterns of the $\mathrm{Mo}_{6} @ \mathrm{LDH}-2$ before and after the test with the MB degradation show no change as seen in Figure S6. That means the layered structure of $\mathrm{LDH}$ is not modified and the degradation of the MB almost occurs mostly on the outside surface of the Mo 6 @LDH-2 nanosheets. In addition, the MB degradable possibility by $\mathrm{Mo}_{6} @ \mathrm{LDH}-2$ was observed for the concentration reduction of about $66 \%$ for the second recycling run.

In summary, the non-photochemical reactions for the degradation of MB based on the Mo $@$ LDH-2 nanocomposite is suggested by the following equations [36, 37, 38, 55].

(Eq.1) $\mathrm{H}_{2} \mathrm{O}_{2}+\left(\mathrm{Mo}_{6}\right.$ cluster $) \rightarrow\left(\mathrm{Mo}_{6}\right.$ cluster $)\left(\mathrm{h}^{+}\right)+\mathrm{OH}^{\circ}+\mathrm{OH}^{-}$ 
454

455

456

457

458

459

460

461

462

463

464

465

466

467

468

469

470

471

472

473

474

475

(Eq.2) $\left(\mathrm{Mo}_{6}\right.$ cluster $)+\mathrm{h} v \rightarrow\left(\mathrm{Mo}_{6}\right.$ cluster $)\left(\mathrm{h}^{+}, \mathrm{e}-\right)$

$\left(\right.$ Eq.3) $\left(\mathrm{Mo}_{6}\right.$ cluster $)\left(\mathrm{h}^{+}\right)+\mathrm{H}_{2} \mathrm{O} \rightarrow\left(\mathrm{Mo}_{6}\right.$ cluster $)+\mathrm{OH}+\mathrm{H}^{+}$

(Eq.4) $\left(\mathrm{Mo}_{6}\right.$ cluster $)\left(\mathrm{e}^{-}\right)+\mathrm{O}_{2} \rightarrow\left(\mathrm{Mo}_{6}\right.$ cluster $)+\mathrm{O}_{2}^{-}$

(Eq.5) $\mathrm{H}_{2} \mathrm{O}_{2}+\mathrm{h} v \rightarrow 2 \mathrm{OH}$

(Eq.6) $\mathrm{H}_{2} \mathrm{O}_{2}+\mathrm{O}_{2}^{-\cdot} \rightarrow{ }^{\cdot} \mathrm{OH}+{ }^{-} \mathrm{OH}+\mathrm{O}_{2}$

(Eq.7) $\mathrm{H}_{2} \mathrm{O}_{2}+\mathrm{OH} \rightarrow \mathrm{O}_{2} \mathrm{H}+\mathrm{H}_{2} \mathrm{O}$

The $\mathrm{Mo}_{6}$ cluster plays an important role as an electron supplying source for the initial reaction with the strong support of $\mathrm{H}_{2} \mathrm{O}_{2}$ to generate free radicals as seen in Eq. 1. The radical generating process is less efficient when the $\mathrm{Mo}_{6}$ cluster is excited by UV light because of taking two steps as depicted by Eq. 2 and Eq. 3 to form hydroxyl radicals $\left(\mathrm{OH}^{\circ}\right)$, and Eq. 4 to form superoxide radical $\left(\mathrm{O}_{2}{ }^{-}\right)$. For this reason, Mo ${ }_{6} @ \mathrm{LDH}-2$ with $\mathrm{H}_{2} \mathrm{O}_{2}$ presents a higher catalytic activity than $\mathrm{Mo}_{6} @ \mathrm{LDH}-2$ with UV light. During the initiating process by $\mathrm{Mo}_{6} @ \mathrm{LDH}-2$ with $\mathrm{H}_{2} \mathrm{O}_{2}$ and UV light, the Eq. 5 and Eq. 6 site reactions could significantly occur to reduce the $\mathrm{H}_{2} \mathrm{O}_{2}$. The degradation rates of the pollutants will decrease with the increase in the $\mathrm{H}_{2} \mathrm{O}_{2}$ concentration despite Eq. 7. The generated hydroxyl radical can randomly attack the MB organic compound by hydrogen abstraction, electron transfer, and radical combination to form the oxidation products $[56]$.

The representation of the structure and activity mechanism of $\mathrm{Mo}_{6} @ \mathrm{LDH}-2$ for the degradation of MB is illustrated in Figure 8. The efficiency of the catalytic activity depends on the generation of highly reactive radicals and the stability of the radicals. Without the light irradiation, $\mathrm{ZnAl}-\mathrm{LDH}$ acts as a weak basic catalyst with the 
hydroxide group the surface. $\mathrm{ZnAl}-\mathrm{LDH}$ did not show the photocatalytic possibility due to the weak performance of the $\mathrm{Zn}$ metal in the photocatalytic reaction [39]. In addition, dye degradation was caused by the photocatalytic and oxidizing reactions. As a result, the catalytic property of the $\mathrm{Mo}_{6} @ \mathrm{LDH}-2$ was mostly originated from the photoactive and oxidizing Mo metal cluster and the absorption caused by LDH. In the reduced form, the valence electron concentration (VEC) occupying in the d orbitals of the six Mo atoms, is equal to 24 electrons per $\mathrm{Mo}_{6}$ cluster unit and it is reduced by a strong oxidizing agent [31]. Moreover, a chemically and an electrochemically reversible system has been reported. The $\mathrm{Mo}_{6}$ cluster unit also provides one electron when excited by the light and transfer to $\mathrm{O}_{2}$ to form singlet oxygen $\left(\mathrm{O}_{1}\right)$ thus exhibiting a powerful oxidant property $[30,32]$. It could be summarized in this study that i) the reducing form of the $\mathrm{Mo}_{6}$ cluster can oxidize the MB molecules, ii) the $\mathrm{Mo}_{6}$ cluster can combine with $\mathrm{H}_{2} \mathrm{O}_{2}$ to create powerful, oxidizing hydroxides $\left(\mathrm{OH}^{\cdot}\right)$, ii) the $\mathrm{Mo}_{6}$ cluster can be excited by the UV light to form the hole and electron pair on the photoexcited cluster which reacts with $\mathrm{H}_{2} \mathrm{O}$ molecules to create the $\mathrm{OH}$ radicals, and superoxide radical $\left(\mathrm{O}_{2}^{-\cdot}\right)$, particularly, singlet oxygen $\left(\mathrm{O}_{1}\right)$ as a powerful oxidant caused by photoluminescence [36,37,38]. The oxygen-based radicals will first attack the $\mathrm{C}=\mathrm{S}+\mathrm{-C}$ linking of the $\mathrm{MB}$ molecule existing on the surface of the LDH. A degradation mechanism of MB caused by the oxygen-based radical is reported to form hydroxylation and oxidation products in a previous study [57]. To understand the impact of the UV light on the catalytic reaction, we consider some possible reasons. The UV light at $370 \mathrm{~nm}$ was used with the purpose to optimally create the $\mathrm{O}_{1}, \mathrm{O}_{2}{ }^{-}$and $\mathrm{OH}$ oxygen-based radicals on the $\mathrm{Mo}_{6}$ cluster which directly react with MB. Unfortunately, from Figure 3, the UV light at $370 \mathrm{~nm}$ is partially absorbed by the $\mathrm{Zn}-\mathrm{Al}$ hydroxide layers that cause the decrease of the excitation photon 
used for the $\mathrm{Mo}_{6}$ cluster. In addition, the hole in the photoexcited $\mathrm{Mo}_{6}$ cluster also reacts with water to form protons which reduce the concentration of the $\mathrm{OH}$ radicals. In the catalyst with the $\mathrm{H}_{2} \mathrm{O}_{2} / \mathrm{UV}$ system, the $\mathrm{H}_{2} \mathrm{O}_{2}$ molecules could be degraded by the UV energy. For this reason, the UV light will negatively affect the MB reducing the efficiency of the $\mathrm{Mo}_{6}$ cluster when UV light and $\mathrm{H}_{2} \mathrm{O}_{2}$ are used at the same time. In summary, the prominent catalytic activity of the $\mathrm{Mo}_{6}$ cluster stabilized on $\mathrm{ZnAl-LDH}$ has been confirmed. The combination of the LDH with high absorbability and the recyclability and the chemically reserving $\mathrm{Mo}_{6}$ cluster will be a promising candidate as a homogeneous catalyst for gas reactions with a strong selection based on the layer structure.

\section{CONCLUSIONS}

A heterogeneous nanocomposite of $\mathrm{ZnAl-LDH}$ functionalized with the molybdenum octahedral cluster ( 16.7 wt. \%) was successfully synthesized by the precipitation and anion exchanging method under ambient conditions. The partially exfoliated ZnALLDH functionalized with the $\mathrm{Mo}_{6}$ cluster was carried out. The interaction between the $\mathrm{Mo}_{6}$ clusters and $\mathrm{ZnAl-LDH}$ is suggested to be via hydrogen bonding and/or new Mo$\mathrm{O}-\mathrm{Al} / \mathrm{Zn}$ covalent linkage. The photoactive and oxidation of the $\mathrm{Mo}_{6}$ cluster in the $\mathrm{Mo}_{6} @ \mathrm{LDH}$ nanocomposite present the important role to degrade methylene blue (MB). This point was investigated under $\mathrm{UV}(\lambda=370 \mathrm{~nm})$, in the presence of $\mathrm{H}_{2} \mathrm{O}_{2}$, or both of $\mathrm{UV}$ and $\mathrm{H}_{2} \mathrm{O}_{2}$ as radical initial agents. The efficiency of the degradation of MB using the $\mathrm{Mo}_{6} @ \mathrm{LDH}-2$ nanocomposite is evaluated at more than about $90 \mathrm{wt} \%$ after $2 \mathrm{~h}$ with $\mathrm{H}_{2} \mathrm{O}_{2}$ as optimal co-agent. These results proved that the octahedral $\mathrm{Mo}_{6}$ clusters are efficiently retained on the brucite-like layers that provide new heterogeneous catalytic 
materials' family for gas reactions in the future.

\section{ACKNOWLEDGMENT}

These studies were carried out as a part of the France-Japan International Collaboration Framework (UMI3629 LINK). The authors wish to thank Mr. D. Lechevalier and Dr. M. many supports involved in LINK and related activities. We also wish to thank Dr. C. Zhang at NIMS for his help with the EPD experiments, Dr. A. Iwanade at NIMS for his help with the ICP-OES measurement and Dr. H. Ohata at NIMS for his help with the XPS measurements.

534

APPENDIX A. SUPPLEMENTARY MATERIAL

Supplementary data to this article can be found online at

\section{REFERENCES}

1. Pirila, M., Drault, F., Keiski, R.L., Saouabe, M., Valtanen, A., Ojala, S., Huuhtanen, M., Rathnayake, B., Brahmi, R., 2015. Photocatalytic Degradation of Organic Pollutants in Wastewater. Top Catal. 58, 1085-1099.

2. Bagheri, S., Yousefi, A.T., Do, T.O., 2017. Photocatalytic pathway toward

543 degradation of environmental pharmaceutical pollutants: structure, kinetics and 544 mechanism approach, Catal. Sci. Technol., 7, 4548-4569.

545 3. Fanourakis, S.K., Peña-Bahamonde, J., Bandara, P.C., Rodrigues, D.F., 2020. Nano-

546 based adsorbent and photocatalyst use for pharmaceutical contaminant removal during 
indirect potable water reuse, npj Clean Water, 3, 1-15.

4. Mohapatra, L., Parida, K., 2016. A review on the recent progress, challenges and perspective of layered double hydroxides as promising photocatalysts, J. Mater. Chem. A, 4, 10744-10766.

5. Chubar, N., Gilmour, R., Gerda, V., Mičušík, M., Omastova, M., Heister, K., Man, P., Fraissard, J., Zaitsev, V., 2017. Layered double hydroxides as the next generation inorganic anion exchangers: Synthetic methods versus applicability, Adv. Colloid and Inter. Sci. 245, 62-80.

6. Meng, Z., Zhang, Y., Zhanga, Q., Chena, X., Liua, L., Komarneni, S., Lva, L., 2017. Novel synthesis of layered double hydroxides (LDHs) from zinc hydroxide, App. Surf. Sci. 396, 799-803.

7. Ahmed, A. A. A., Tali, Z. A., Hussein, M. Z., Zakaria, A., 2012. Zn-Al layered double hydroxide prepared at different molar ratios: Preparation, characterization, optical and dielectric properties, J. Solid State Chem. 191, 271-278.

8. Kim, S. J., Lee, Y., Lee, D. K., Lee, J. W., Kang, J.K., 2014. Efficient Co-Fe layered double hydroxide photocatalysts for water oxidation under visible light, J. Mater. Chem. A, 2, 4136-4139.

564

9. Chowdhury, P. R., Bhattacharyya, K. G., 2015. Synthesis and characterization of 565 $\mathrm{Co} / \mathrm{Ti}$ layered double hydroxide and its application as a photocatalyst for degradation of aqueous Congo Red, RSC Adv. 5, 92189-92206.

10. Zheng, Y., Chen, Y., 2017. Preparation of polypropylene/Mg-Al layered double hydroxides nanocomposites through wet pan-milling: formation of a second-staging structure in LDHs intercalates. RSC Adv. 7, 1520-1530.

570 11. Fu, Y., Ning, F., Xu, S., An, H., Shao, M., Wei, M., 2016. Terbium doped ZnCr- 
layered double hydroxides with largely enhanced visible light photocatalytic performance, J. Mater. Chem. A 4, 3907-3913.

12. Ma, L., Wang, Q., Islam, S. M., Liu, Y., Ma, S., Kanatzidis, M. G., 2016. Highly selective and efficient removal of heavy metals by layered double hydroxide intercalated with the $\mathrm{MoS}_{4}{ }^{2-}$ ion, J. Am. Chem. Soc. 138, 2858-2866.

13. Fan, G., Li, F., Evans, D. G., Duan, X. 2014. Catalytic applications of layered double hydroxides: recent advances and perspectives, Chem. Soc. Rev. 43, 7040-7066 14. Wu, M. J., Wu, J. Z., Zhang, J., Chen, H., Zhou, J. Z., Qian, G. R., Xu, Z. P., Dud, Z., Rao, Q. L., 2018. A review on fabricating heterostructures from layered double hydroxides for enhanced photocatalytic activities, Catal. Sci. Technol. 8,1207-1228. 15. Patel, R., Park, J. T., Patel, M., Dash, J. K., Gowd, E. B., Karpoormath, R., Mishra, A., Kwak, J., Kim, J. H., 2018. Transition-metal-based layered double hydroxides tailored for energy conversion and storage, J. Mater. Chem. A 6, 12-29.

16. Barahuie, F., Hussein, M.Z., Arulselvan, P., Fakurazi, S., Zainal, Z., 2014. Drug delivery system for an anticancer agent, chlorogenate-Zn/Al-layered double hydroxide nanohybrid synthesised using direct co-precipitation and ion exchange methods, J. Solid State Chem. 217, 31-41.

17. Fontes, D.A.F., Lyra, M.A.M., Andrad, J. K. F., Schver, G. C. R., Rolim, L.A., Silva, T. G., Soares-Sobrinho, J.L., Alves-Junior, S., Rolim-Neto, P.J., 2016. CaAl-layered double hydroxide as a drug delivery system: effects on solubility and toxicity of the antiretroviral efavirenz, J. Incl. Phenom. Macrocycl. Chem., 85, 281-288.

18. Kura, A.U., Hussein, M.Z., Fakurazi, S., Arulselvan, P., 2014. Layered double hydroxide nanocomposite for drug delivery systems; bio-distribution, toxicity and drug activity enhancement, Chem. Central J. 8, 47-55. 
595

596

597

598

599

600

601

602

603

604

605

606

607

608

609

610

611

612

613

614

615

616

617

618

19. Sahoo, M., Singha, S., Parida, K. M., 2011. Amine functionalized layered double hydroxide: a reusable catalyst for aldol condensation, New J. Chem. 35, 2503-2509.

20. Shao, M., Ning, F., Zhao, J., Wei, M., Evans, D.G., Duan, X., 2013. Hierarchical layered double hydroxide microspheres with largely enhanced performance for ethanol electrooxidation, Adv. Funct. Mater. 23, 3513-3518.

21. Zhao, Y., Zhao, Y., Waterhouse, G. I .N., Zheng, L., Cao, X., Teng, F., Wu, L. Z., Tung, C.H., O’Hare, D., Zhang, T., 2017. Layered-Double-Hydroxide nanosheets as efficient visible-light-driven photocatalysts for dinitrogen fixation, Adv. Mater. 29, 1703828-1703838.

22. Zhang, j., Liu, J., Xi, L., Yu, Y., Ning Chen, .N, Sun, S., Wang, W., Lange, K.M., Zhang, B., 2018. Single-Atom Au/NiFe Layered Double Hydroxide Electrocatalyst: Probing the Origin of Activity for Oxygen Evolution Reaction, J. Am. Chem. Soc., 140, $3876-3879$.

23. Iqbal, K., Iqbal, A., Kirillov, A.M., Wang, B., Liu, W., Tang, Y., 2017. A new Cedoped MgAl-LDHs@Au nanocatalyst for highly efficient reductive degradation of organic contaminants. J. Mater. Chem. A, 5, 6716-6724.

24. Liu, J.C., Qi, B., Song, I.F., 2020, Engineering polyoxometalate-intercalated layered double hydroxides for catalytic applications, Dalton Trans., 49, 3934-3941.

25. Cotton, F.A., 1964. Metal Atom Clusters in Oxide Systems. Inorg. Chem. 3, $1217-$ 1220.

26. Nguyen, T. K. N., Renaud, A., Bierre, B., Bouteille, B., Wilmet, M., Dubernet, M., Ohashi, N., Grasset, F., Uchikoshi, T. Extended Study on Electrophoretic Deposition Process of Inorganic Octahedral Metal Clusters: Advanced Multifunctional Transparent Nanocomposite Thin Films, Bull. Chem. Soc. Jpn., 2018, 91, 1763-1774. 
619

620

621

622

623

624

625

626

627

628

629

630

631

632

633

634

635

636

637

638

639

640

641

642

27. Neaime, C., Amela-Cortes, M., Grasset, F., Molard, Y., Cordier, S., Dierre, B., Mortier, M., Takei, T., Takahashi, K., Haneda, H., Verelst, M., Lechevallier, S., 2016. Time-gated luminescence bioimaging with new luminescent nanocolloids based on $\left[\mathrm{Mo}_{6} \mathrm{I}_{8}\left(\mathrm{C}_{2} \mathrm{~F}_{5} \mathrm{COO}\right)_{6}\right]^{2-}$ metal atom clusters, Phys. Chem. Chem. Phys. 18, 30166-30173.

28. Efremova, O.A., Brylev, K.A., Vorotnikov, Y.A., Vejsadova, L., Shestopalov, M.A., Chimonides, G.F, Mikes, P., Topham, P.D., Kim, S.J., Kitamurah, N., Sutherland, A.J., 2016. Photoluminescent materials based on PMMA and a highly-emissive octahedral molybdenum metal cluster complex. J. Mater. Chem. C, 4, 497-503.

29. Kirakci, K., Kubát, P., Dusek, M., Fejfarová, K., Sícha, V., Mosinger, J., Lang, K., 2012. A Highly Luminescent Hexanuclear Molybdenum Cluster-A Promising Candidate toward Photoactive Materials, Eur. J. Inorg. Chem. 19, 3107-3111.

30. Kirakci, K., Kubát, P., Langmaier, J., Polívka, T., Fuciman, M., Fejfarovád, K., Lang, K.A., 2013. Comparative study of the redox and excited state properties of $\left(\mathrm{nBu}_{4} \mathrm{~N}\right)_{2}\left[\mathrm{Mo}_{6} \mathrm{X}_{14}\right]$ and $\left(\mathrm{nBu}_{4} \mathrm{~N}\right)_{2}\left[\mathrm{Mo}_{6} \mathrm{X}_{8}\left(\mathrm{CF}_{3} \mathrm{COO}\right)_{6}\right](\mathrm{X}=\mathrm{Cl}, \mathrm{Br}$, or I), Dalton Trans. $42,7224-7232$.

31. Vorotnikova, N.A., Vorotnikov, Y.A., Novozhilov, I. N., Syrokvashin, M.M., Nadolinny, V.A., Kuratieva, N.V., Benoit, D.M., Mironov, Y.V., Walton, R.I., Clarkson, G.J., Kitamura, N., Sutherland, A.J., Shestopalov, M.A., Efremova, O.A., 2018. ${ }^{23}$ Electron Octahedral Molybdenum Cluster Complex $\left[\left\{\mathrm{Mo}_{6} \mathrm{I}_{8}\right\} \mathrm{Cl}_{6}\right]^{-}$, Inorg. Chem. 57, 811-820.

32. Costuas, K., Bulou, A.A., Fontaine, B., Cuny, J., Gautier, R., Mortier, M., Molard, Y., Duvail, J.L., Faulques, E., Cordier, S., 2015. Combined theoretical and time-resolved photoluminescence investigations of $\left[\mathrm{Mo}_{6} \mathrm{Br}_{8}^{\mathrm{i}} \mathrm{Br}_{6}^{\mathrm{a}}\right]$ metal cluster units: evidence of dual emission, Phys. Chem. Chem. Phys. 17, 28574-28585. 

Phys. Chem. A. 94, 4500-4507.

Situ Generation of Active Molybdenum Octahedral Clusters for Photocatalytic Hydrogen Production from Water, Chem. Sus. Chem. 9, 1963-1971.

35. Ivanova, M.N., Vorotnikov, Y.A., Plotnikova, E.E., Marchuk, V.M., Ivanov, A.A., Asanov, I.P., Tsygankova, A.R., Grayfer,E.D., Fedorov, V.E., Shestopalo, M.A., 2020, Hexamolybdenum Clusters Supported on Exfoliated h-BN Nanosheets for Photocatalytic Water Purification, Inorg. Chem., 59, 6439-6448. Oxide Supported Molybdenum Cluster: First Heterogenized Homogeneous Catalyst for the Synthesis of Dimethylcarbonate from $\mathrm{CO}_{2}$ and Methanol, Chem. Eur. J. 21, 3488 3494.

37. Barras, A., Devarapallic, M.R., Shelkec, R.R., Cordier, S., M.V., Szunerits, S., Boukherroub, R., 2013. One-pot synthesis of gold nanoparticle/molybdenum 659 cluster/graphene oxide nanocomposite and its photocatalytic activity, App. Cat. B: Envi. 660 270- 276, 130-131.

38. Barras, A., Cordier, S., Boukherroub, R., 2012. Fast photocatalytic degradation of 662 rhodamine B over $\left[\mathrm{Mo}_{6} \mathrm{Br}_{8}\left(\mathrm{~N}_{3}\right)_{6}\right]^{2-}$ cluster units under sun light irradiation, Appl. Cat. 663 B: Envi. 123-124, $1-8$. 39. Yang, Y., Zhang, C., Zeng, G., Tan, X., Wang, H., Huang, D., Yang, K., Wei, J., Maab, C., Niec, K., 2020. Design and engineering of layered double hydroxide based catalysts for water depollution by advanced oxidation processes: a review, J. Mater. 
668

669

670

40. Starukh, G., 2017. Photocatalytically enhanced cationic dye removal with Zn-Al layered double hydroxides. Nanoscale Research Lett. 12, 391-399.

41. Saito, N., Lemoine, P., Dumait, N., Amela-Cortes, M., Paofai, S., Roisnel, T., Nassif, V., Grasset, F., Wada, Y., Ohashi, N., Cordier, S., 2017. From $\mathrm{Cs}_{2} \mathrm{Mo}_{6} \mathrm{Cl}_{14}$ to $\mathrm{Cs}_{2} \mathrm{Mo}_{6} \mathrm{Cl}_{14}$ center dot $\mathrm{H}_{2} \mathrm{O}$ and Vice Versa: Crystal Chemistry Investigations, J. Clust. Sci. 28, 773-798.

42. Kirakci, K., Cordier, S., Perrin, C., 2005. Synthesis and characterization of $\mathrm{Cs}_{2} \mathrm{Mo}_{6} \mathrm{X}_{14}(\mathrm{X}=\mathrm{Br}$ or $\mathrm{I})$ hexamolybdenum cluster halides: Efficient $\mathrm{Mo}_{6}$ cluster precursors for solution chemistry syntheses. Z. Anorg. Allg. Chem. 631, 411-416.

43. Deng, L., Zeng, H., Zhang, Z.W., Luo, J., Sodium dodecyl sulfate intercalated and acrylamide anchored layered double hydroxides: A multifunctional adsorbent for highly efficient removal of Congo red. J. Colloid and Inter. Sci. 521 (2018) 172-182.

44. Ahmed, A.A.A., Talib, Z.A., Hussein, M.Z., 2015. Influence of sodium dodecyl sulfate concentration on the photocatalytic activity and dielectric properties of intercalated sodium dodecyl sulfate into $\mathrm{Zn}-\mathrm{Cd}-\mathrm{Al}$ layered double hydroxide, Mater. Research Bulletin. 62, 122-131.

45. Zarate, X., Schott, E., Soto, L.A., Tagle, R.R., 2013. A family of octahedral molybdenum cluster complexes $\left[\mathrm{Mo}_{6} \mathrm{Cl}_{8}\left(\mathrm{H}_{2} \mathrm{O}\right)_{\mathrm{n}}(\mathrm{OH})_{6-\mathrm{n}}\right]^{\mathrm{n}-2}$ with $\mathrm{n}=0-6$ as a $\mathrm{pH}-$ sensors: A theoretical study, Chem. Phys. Lett. 567, 39-42.

46. Chuntonov, L., Kumar, R., Kuroda, D.G., 2014. Non-linear infrared spectroscopy of the water bending mode: direct experimental evidence of hydration shell reorganization. Chem. Chem. Phys., 16, 13172-13181.

47. Nguyen, T.K.N., Dierre, B., Grasset, F., Renaud, A., Cordier, S., Lemoine, P., 

(Zn, Al) layered double hydroxides, Surf. Interface Anal. 48, 514-518.

49. Galtayries, A., Wisniewski, S., Grimblot, J., 1997. Formation of thin oxide and sulphide films on polycrystalline molybdenum foils: characterization by XPS and surface potential variations. J. Electron Spectroscopy and Related Phenomena, 87, 31 44.

50. Castañeda, S.I., Montero, I., Ripalda, J.M., Díaz, N., Galán, L., Rueda, F., 1999. Xray photoelectron spectroscopy study of low-temperature molybdenum oxidation process, J. Appl. Phys. 85, 8415-8418.

51. Bamroongwongdee, C., Bowker, C. M.A.F., Davies, P. R., Davies, R. J., Edwards, D., 2013. Fabrication of complex model oxide catalysts: Mo oxide supported on $\mathrm{Fe}_{3} \mathrm{O}_{4}(111)$, Faraday Discuss, 162, 201-212.

52. Li, H., Deng, Q., Liu, L., Hou, W., Du, N., Zhang, R., Tao, X., 2014. Synthesis, characterization and enhanced visible light photocatalytic activity of $\mathrm{Bi}_{2} \mathrm{MoO}_{6} / \mathrm{Zn}-\mathrm{Al}$ ed double hydroxide hierarchical heterostructures, Catal. Sci. Technol. 4, 1028-1037. 53. Saito, N., Cordier, S., Lemoine, P., Ohsawa, T., Wada, Y., Grasset, F., Cross, J. S., Ohashi, N., 2017. Lattice and valence electronic structures of crystalline octahedral molybdenum halide clusters-based compounds, $\mathrm{Cs}_{2}\left[\mathrm{Mo}_{6} \mathrm{X}_{14}\right](\mathrm{X}=\mathrm{Cl}, \mathrm{Br}, \mathrm{I})$, studied by density functional theory calculations, Inorg. Chem. 56, 6234-6243. 
advanced oxidation technologies for the removal of organic pollutants from water. Water, Air, Soil \& Pollution, 225, 2102-2148.

55. Gligorovski, S., Strekowski, R., Barbati, S., Vione, D., 2015. Environmental implications of hydroxyl radicals $(\bullet \mathrm{OH})$. Chem. Rev., 115, 13051-13092. 56. Munter, R., 2001. Advanced oxidation processes - current status and prospects. Proc. Estonian Acad. Sci. Chem. 50, 59-80.

57. Xia, S., Zhang, L., Pan, G., Qiana, P., Ni, Z., 2015. Photocatalytic degradation of methylene blue with a nanocomposite system: synthesis, photocatalysis and degradation pathways. Phys. Chem. Chem. Phys., 17, 5345-535.

\section{FIGURE CAPTIONS}

Figure 1. A) Powder-XRD patterns of LDH-1, Mo ${ }_{6} @ L D H-1, L D H-2, \mathrm{Mo}_{6} @ L D H-2$ with the indications of the planes of $003(\boldsymbol{\bullet}), 006(\bullet), 009(\boldsymbol{\Delta})$ and the lozenge symbol ( ) assigned for the $\mathrm{ZnO}$ phase. B) The schematic representation of the process to fabricate the LDH and designed structure of its nanocomposite.

Figure 2. A) The HR-TEM, B) STEM images of the layered structure, and C) profile of spacing distance between the layers, and D) STEM-EDX mapping of the Mo 6 @LDH-2 nanocomposite.

Figure 3. A) UV-Vis absorbance spectra and B) room temperature photoluminescence spectra excited by $325 \mathrm{~nm}$ (He-Cd) laser of CMC cluster, LDH-1, LDH-2, and $\mathrm{Mo}_{6} @ \mathrm{LDH}-2$.

Figure 4. FTIR spectra of CMC cluster and $\mathrm{Mo}_{6} @ \mathrm{LDH}$ nanocomposites.

Figure 5. Thermal analysis of LDH-1, LDH-2, and Mo6@LDH-2

Figure 6. (A) XPS binding energy (eV) spectrum of the CMC powder and the 
Mo6 @LDH-2 nanocomposite, XPS spectra of (B) Mo 3d, (C) Cl 2p region.

740 Deconvolution spectra of $\mathrm{Cl} 2 \mathrm{p}$ region of (D) the CMC and (E) Mo 6 @ LDH-2.

741 Figure 7. A) The MB-degradable possibility caused by (1) Mo 6 cluster, (2) Mo 6 LDH742 2, and (3) LDH-2 without and with $\mathrm{H}_{2} \mathrm{O}_{2}$ during stirring for $2 \mathrm{~h}, \mathrm{~B}$ ) the degradation rate 743 and $\mathrm{C}$ ) the effect of $\mathrm{H}_{2} \mathrm{O}_{2}$ concentrations on MB-degradable possibility by $\mathrm{Mo}_{6} @ \mathrm{LDH}-2$ 744 for 210 minutes with and without UV light $(\lambda=370 \mathrm{~nm})$ illumination.

745 Figure 8. Schematic representation of the heterogeneous activation mechanism of $746 \quad \mathrm{Mo}_{6} @ \mathrm{LDH}-2$ initialed by $\mathrm{UV}(\lambda=370 \mathrm{~nm})$ and $\mathrm{H}_{2} \mathrm{O}_{2}$ oxidation agents.

TABLES

750 Table 1. XPS binding energy $(\mathrm{eV})$ of deconvolution spectra of $\mathrm{Cl} 2 \mathrm{p}$ region of the $751 \quad\left[\mathrm{Mo}_{6} \mathrm{Cl}_{8}^{\mathrm{i}} \mathrm{Cl}_{6}^{\mathrm{a}}\right]^{2}$ anions of CMC cluster and $\mathrm{Mo}_{6} @ \mathrm{LDH}-2$.

752 Table 2. The concentration of the component elements in the CMCpowder and the $753 \mathrm{Mo}_{6} @ \mathrm{LDH}-2$ nanocomposite by the peak analysis of the XPS measurements. 


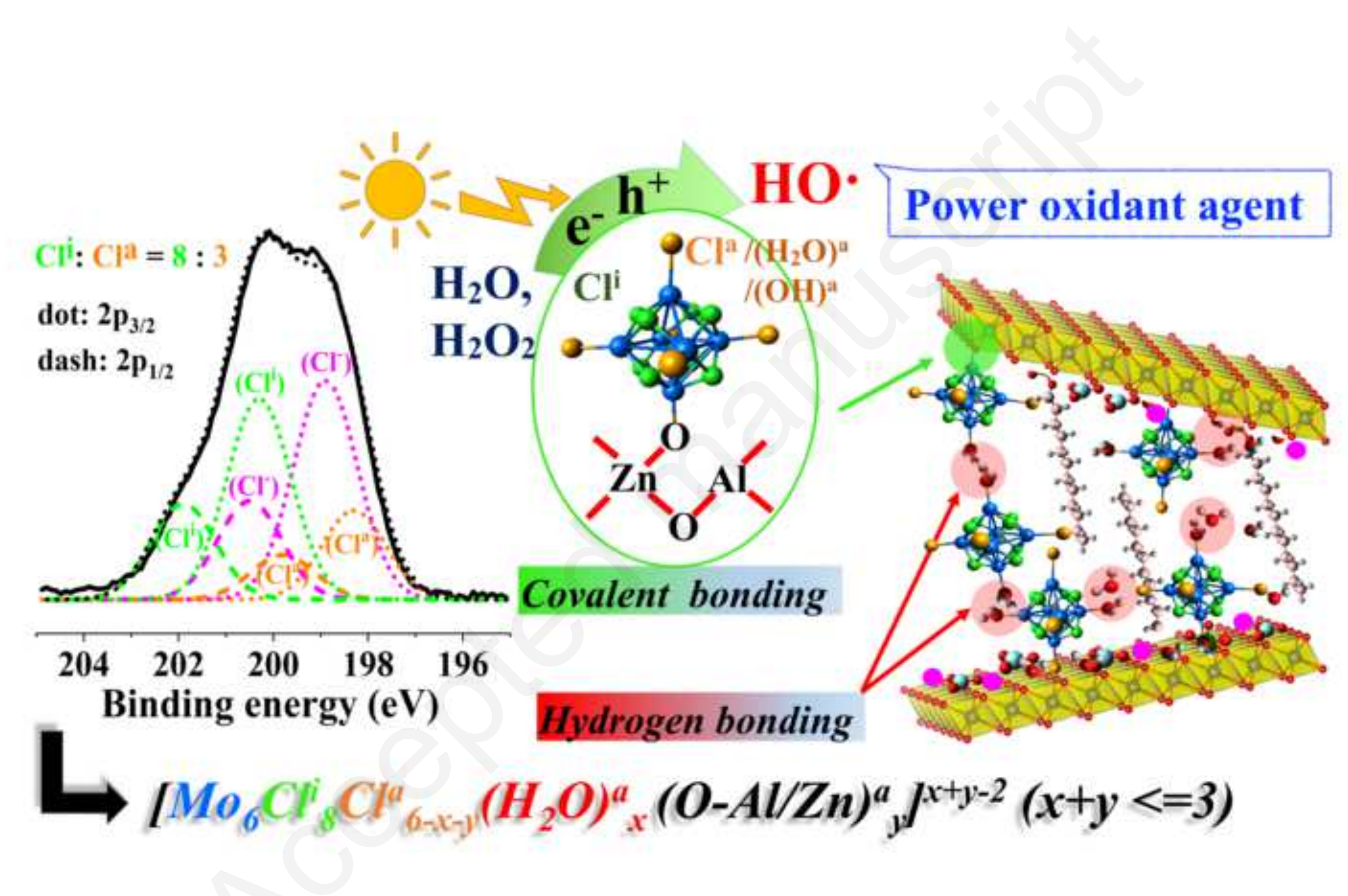

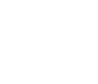




\section{Highlights}

ZnAl-LDHs were successfully functionalized with the hexamolybdenum cluster by covalent linkage.

A Mo6@LDHs nanocomposite retains the photoactive and oxidation properties of the Mo6 cluster

Three nanomaterial phases were found in the lamellar structure of the Mo6@LDHs

$\mathrm{H}_{2} \mathrm{O}_{2} / \mathrm{Mo}_{6} @ L D H s$ efficiently accelerated the degradation reaction of methylene blue with and without UV light illumination 


\section{TABLES}

Table 1. XPS binding energy $(\mathrm{eV})$ of deconvolution spectra of $\mathrm{Cl} 2 \mathrm{p}$ region of the $\left[\mathrm{Mo}_{6} \mathrm{Cl}_{8}^{\mathrm{i}} \mathrm{Cl}_{6}^{\mathrm{a}}\right]^{2}$ anions of $\mathrm{Cs}_{2} \mathrm{Mo}_{6} \mathrm{Cl}_{14}$ cluster and $\mathrm{Mo}_{6} @ \mathrm{LDH}-2$.

\begin{tabular}{|c|c|c|c|c|c|c|}
\hline Sample & B.E & FWHM & Height & $\%$ area & Peak & $\mathrm{Cl}^{\mathrm{i}} / \mathrm{Cl}^{\mathrm{a}} / \mathrm{Cl}^{\text {new }}$ \\
\hline \multirow{4}{*}{$\mathrm{Cs}_{2} \mathrm{Mo}_{6} \mathrm{Cl}_{8}^{\mathrm{i}} \mathrm{Cl}_{6}^{\mathrm{a}}$} & 198.25 & 1.15 & 15637 & 27.88 & $\mathrm{Cl} 2 \mathrm{p}_{3 / 2}$ (a) & \multirow{4}{*}{$8 / 5.8 / 0$} \\
\hline & 199.85 & 1.15 & 7895 & 14.08 & $\mathrm{Cl} 2 \mathrm{p}_{1 / 2}$ (a) & \\
\hline & 200.39 & 1.16 & 21005 & 37.78 & $\mathrm{Cl} 2 \mathrm{p}_{3 / 2}(\mathrm{i})$ & \\
\hline & 201.99 & 1.16 & 11265 & 20.26 & $\mathrm{Cl} 2 \mathrm{p}_{1 / 2}(\mathrm{i})$ & \\
\hline \multirow{6}{*}{$\mathrm{Mo}_{6} @ \mathrm{LDH}-2$} & 198.25 & 1.6 & 977 & 11.90 & $\mathrm{Cl} 2 \mathrm{p}_{3 / 2}$ (a) & \multirow{6}{*}{$8 / 3.6 / 8.6$} \\
\hline & 198.90 & 1.6 & 2403 & 28.28 & $\mathrm{Cl} 2 \mathrm{p}_{3 / 2}$ & \\
\hline & 199.85 & 1.6 & 488 & 5.95 & $\mathrm{Cl} 2 \mathrm{p}_{1 / 2}$ (a) & \\
\hline & 200.35 & 1.6 & 2207 & 26.89 & $\mathrm{Cl} 2 \mathrm{p}_{3 / 2}$ (i) & \\
\hline & 200.50 & 1.6 & 1081 & 13.17 & $\mathrm{Cl} 2 \mathrm{p}_{1 / 2}$ & \\
\hline & 201.95 & 1.6 & 1051 & 12.81 & $\mathrm{Cl} 2 \mathrm{p}_{1 / 2}(\mathrm{i})$ & \\
\hline
\end{tabular}

Table 2. The concentration of the component elements in the $\mathrm{Cs}_{2}\left[\mathrm{Mo}_{6} \mathrm{Cl}_{14}\right]$ powder and the Mo ${ }_{6} @$ LDH-2 nanocomposite by the peak analysis of the XPS measurements.

\begin{tabular}{|l|l|l|}
\hline $\begin{array}{l}\text { Element } \\
\text { component (\%at.) }\end{array}$ & $\mathrm{Cs}_{2} \mathrm{Mo}_{6} \mathrm{Cl}_{14}$ & $\mathrm{Mo}_{6} @ \mathrm{LDH}-2$ \\
\hline $\mathrm{Al}$ & 0 & 3.8 \\
\hline $\mathrm{Zn}$ & 0 & 12.4 \\
\hline $\mathrm{S}$ & 0 & 1.5 \\
\hline $\mathrm{C}$ & 28.5 & 29.1 \\
\hline $\mathrm{O}$ & 5.2 & 47.3 \\
\hline $\mathrm{Cl}$ & 42 & 3.8 \\
\hline $\mathrm{Mo}$ & 17.7 & 2.1 \\
\hline
\end{tabular}




\begin{tabular}{|l|l|l|}
$\mathrm{Cs}$ & 6.6 & 0 \\
\hline $\mathrm{Cs} / \mathrm{Mo} / \mathrm{Cl}$ & $2.2 / 6.0 / 14.2$ & $0 / 6.0 / 10.7$ \\
\hline
\end{tabular}



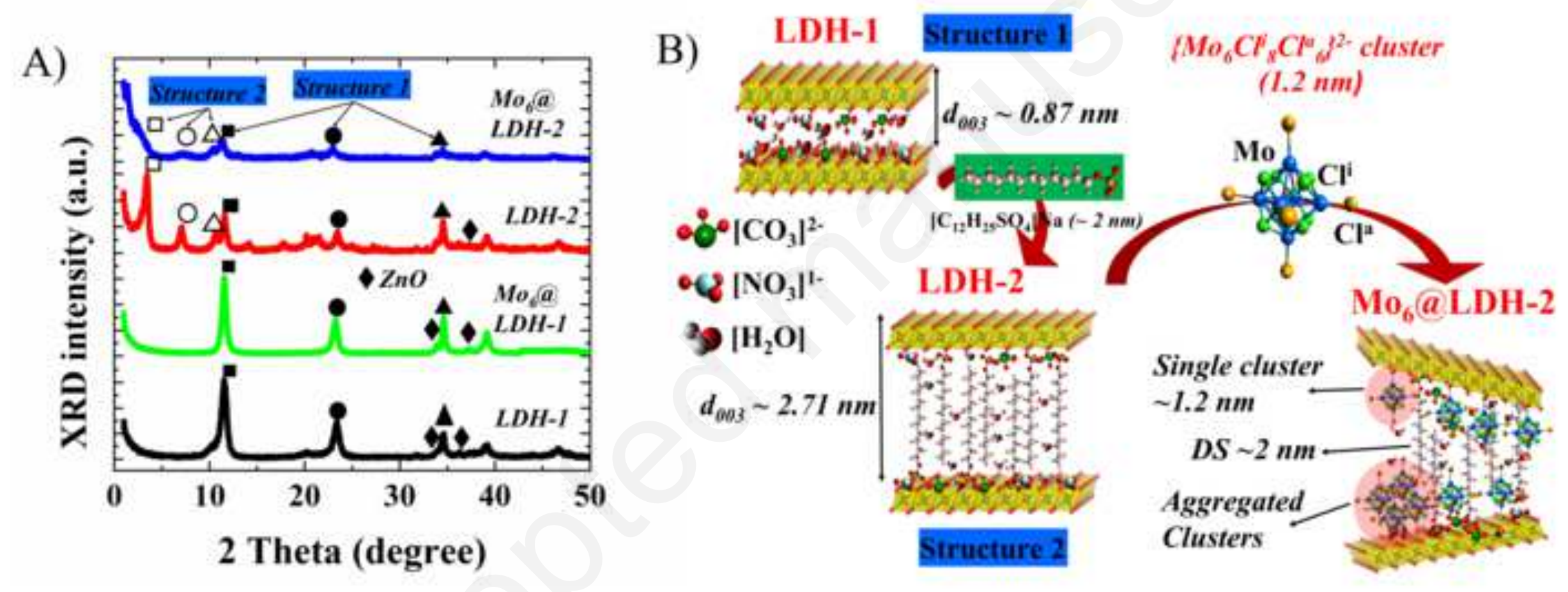
Click here to download high resolution image

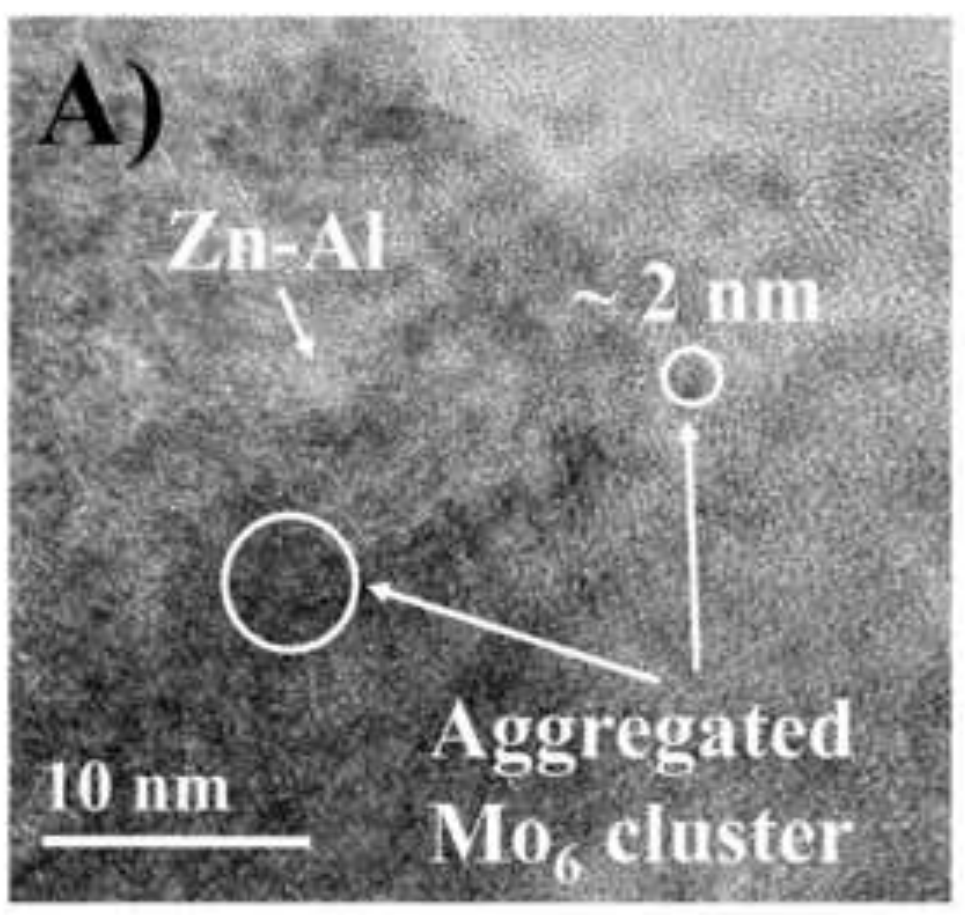

B)

$100 \mathrm{~nm}$
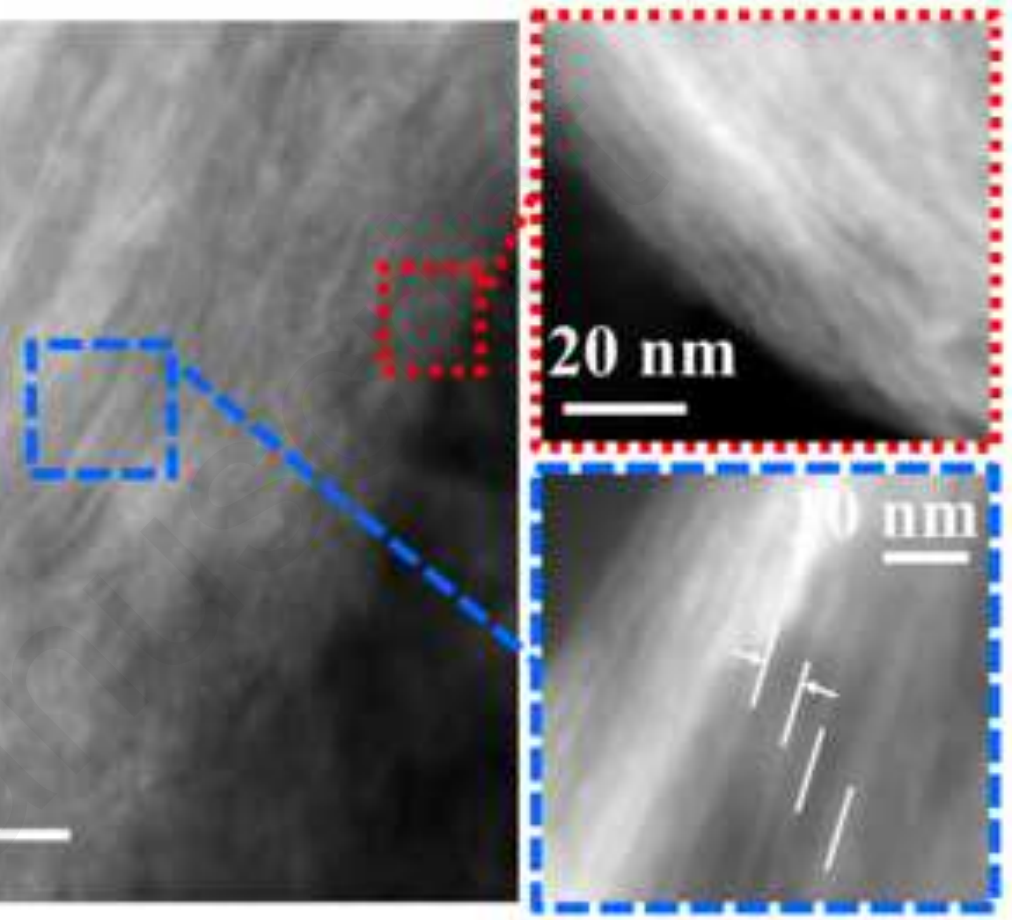
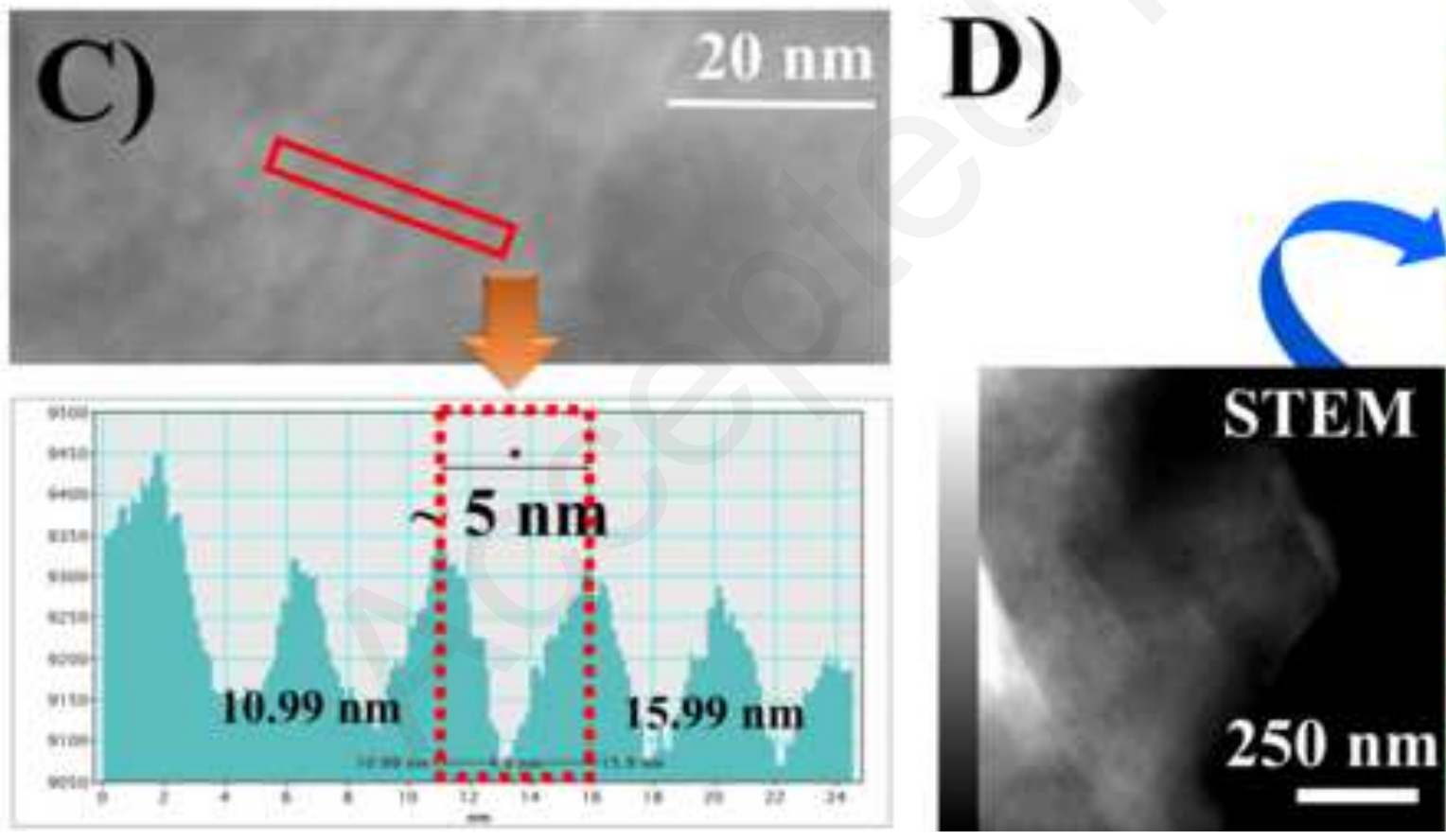

Red dot: $\mathbf{C l}$

Green dot: Mo

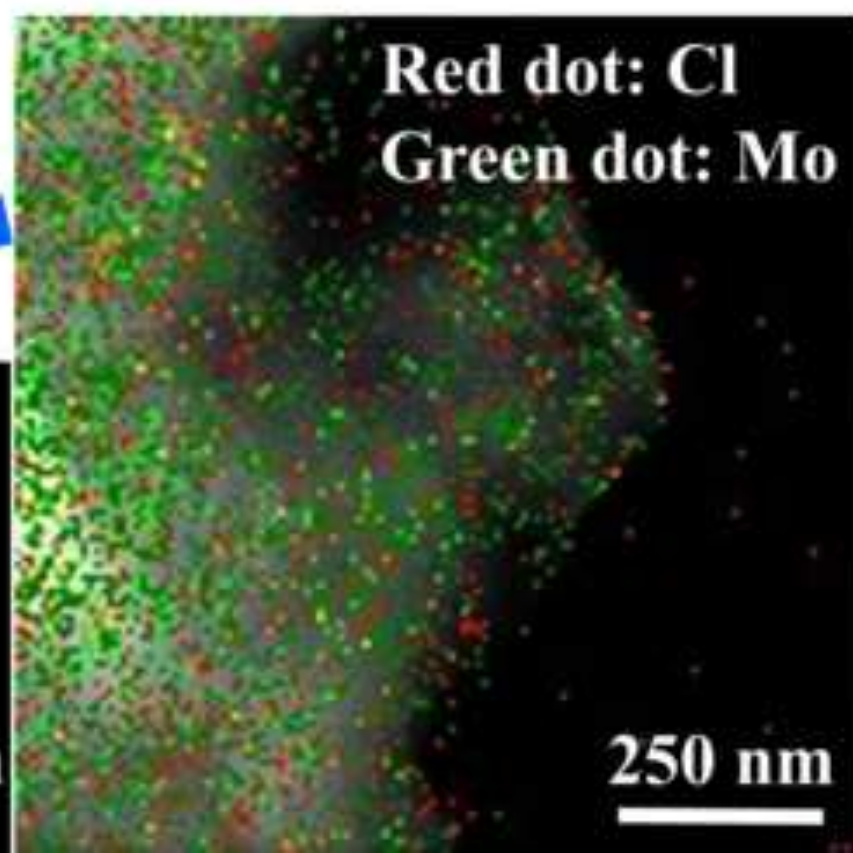



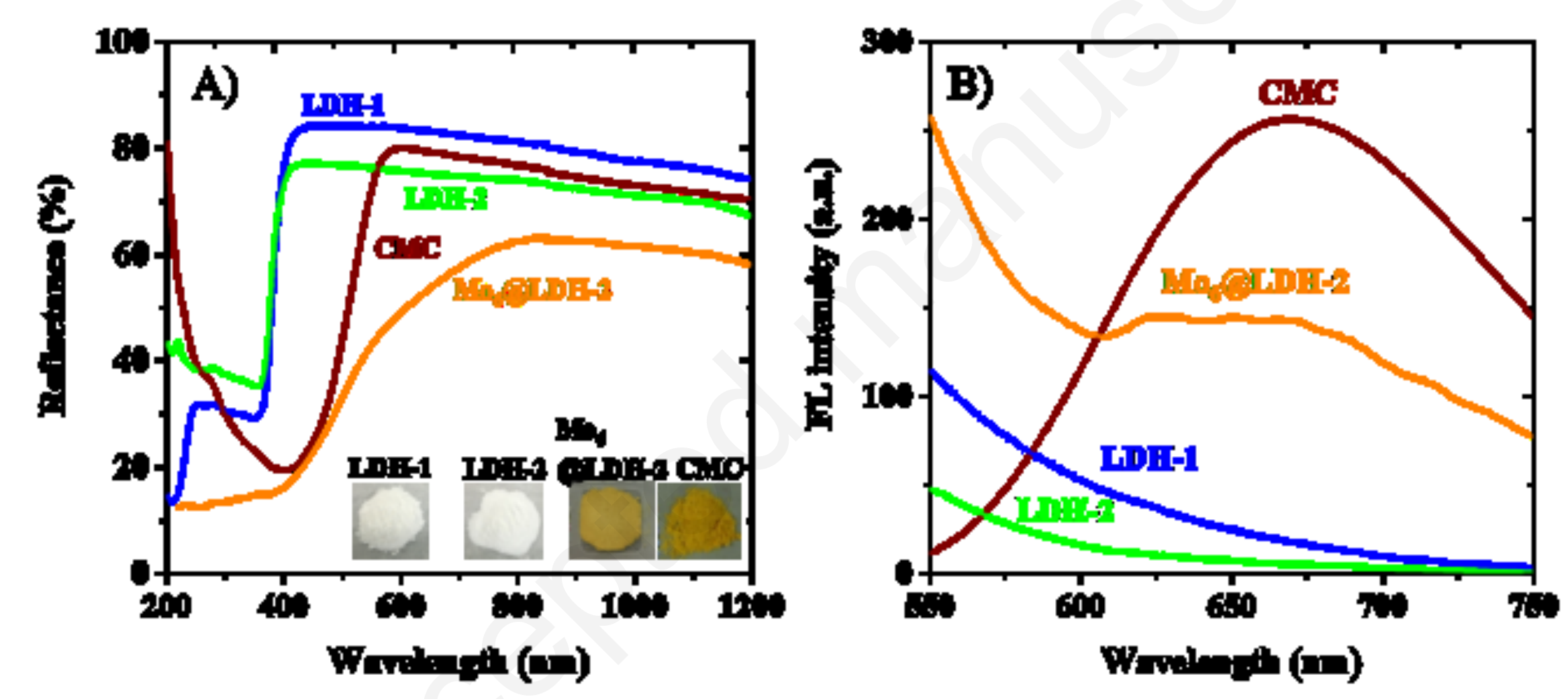


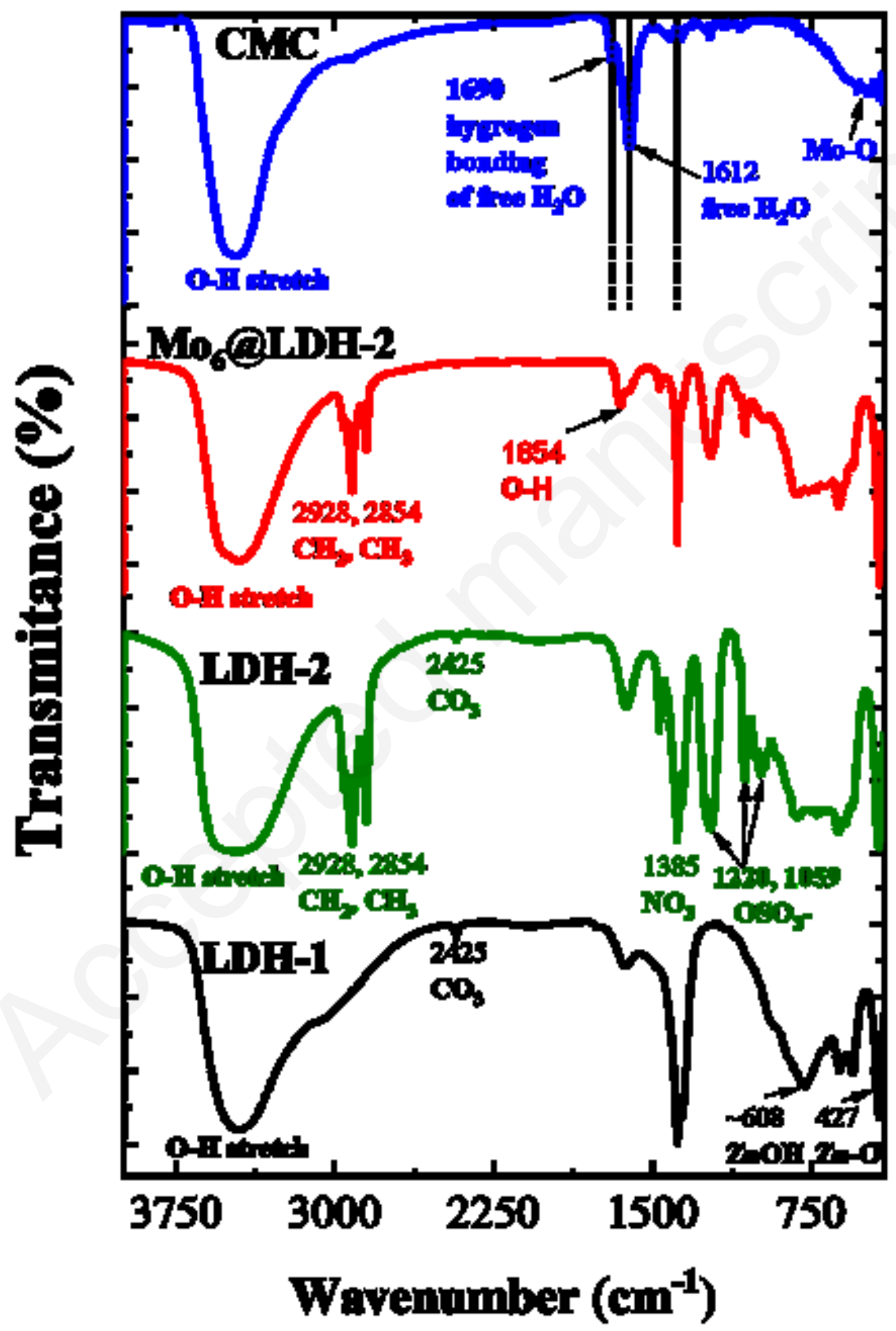




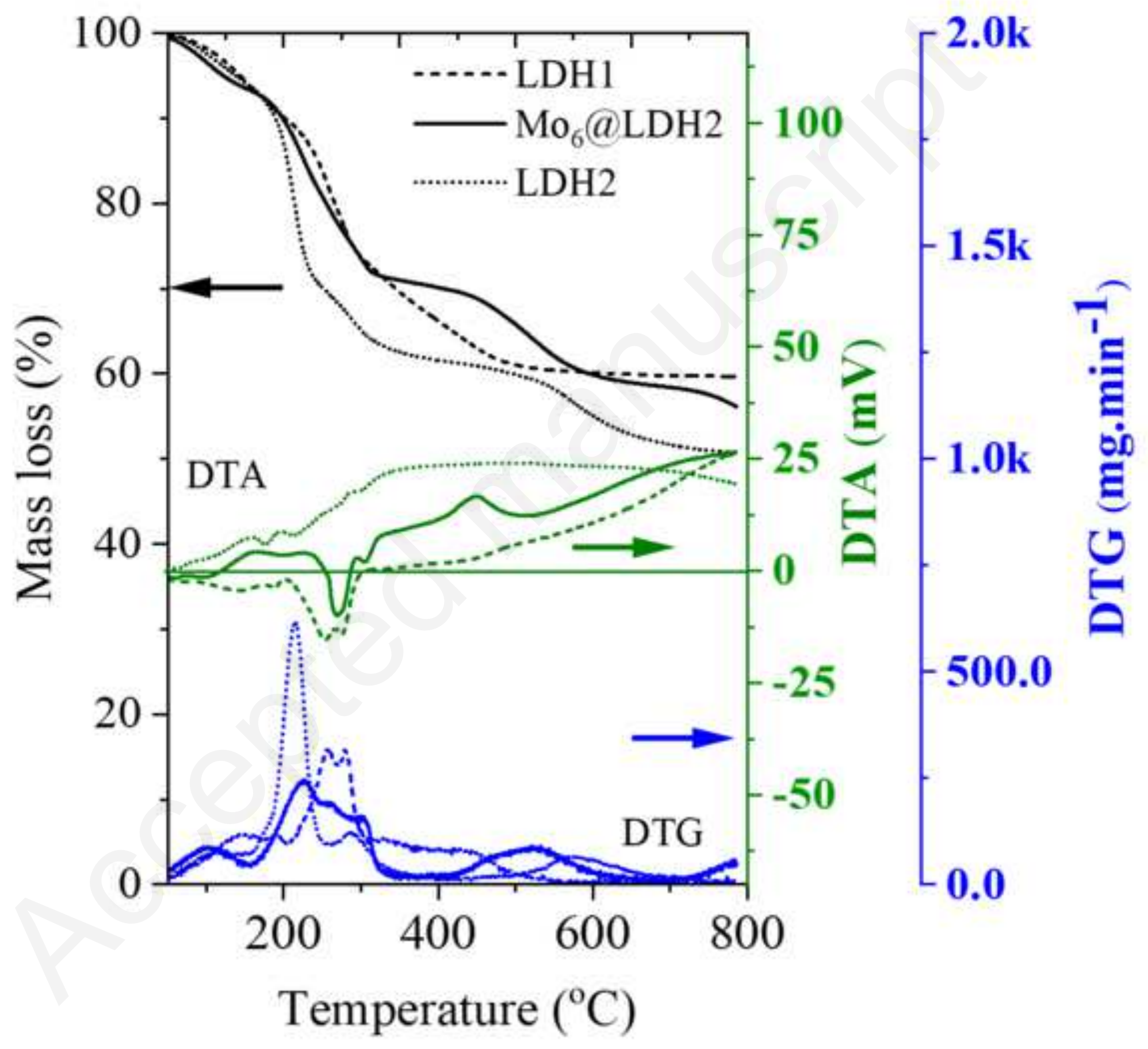



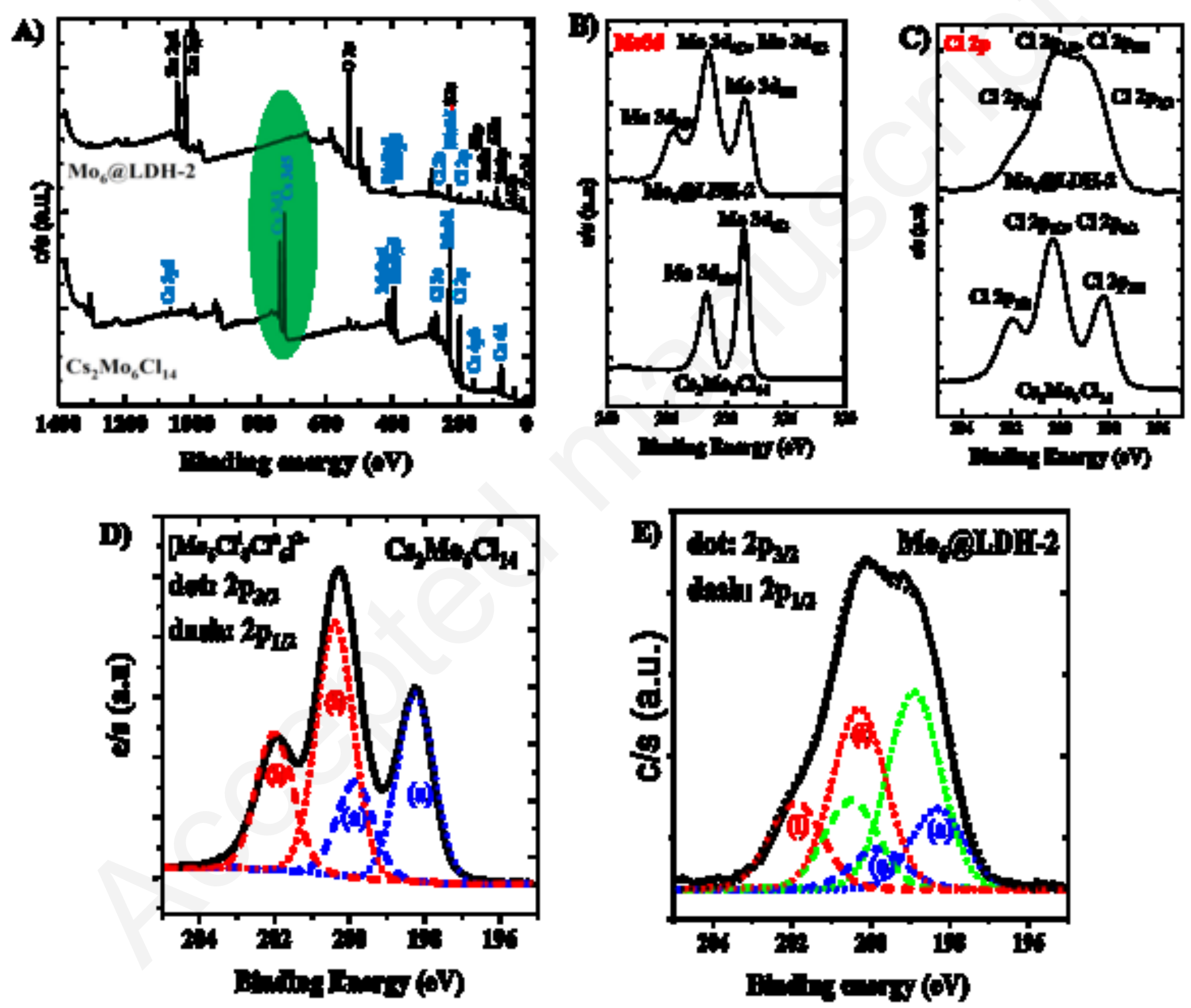

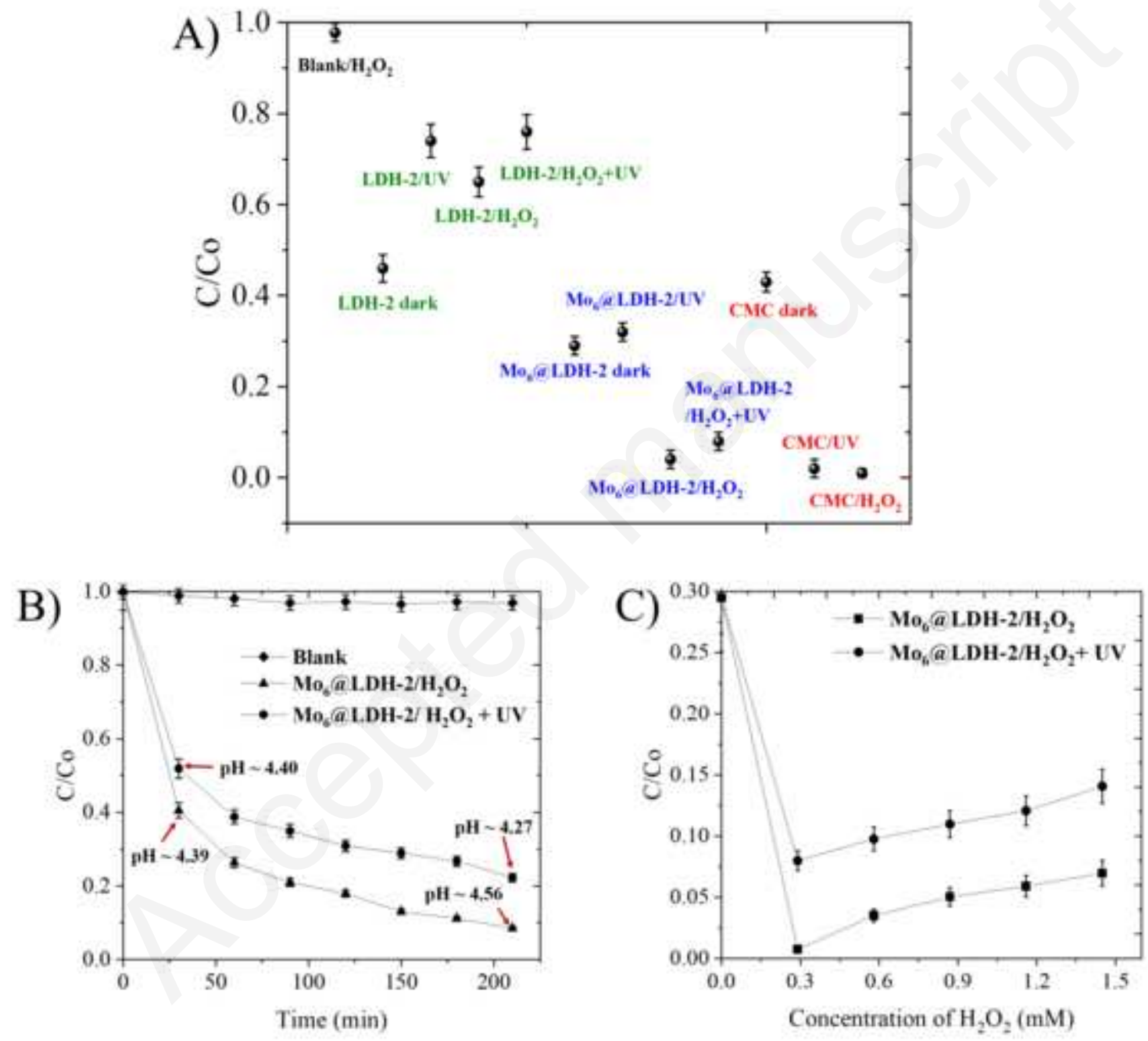


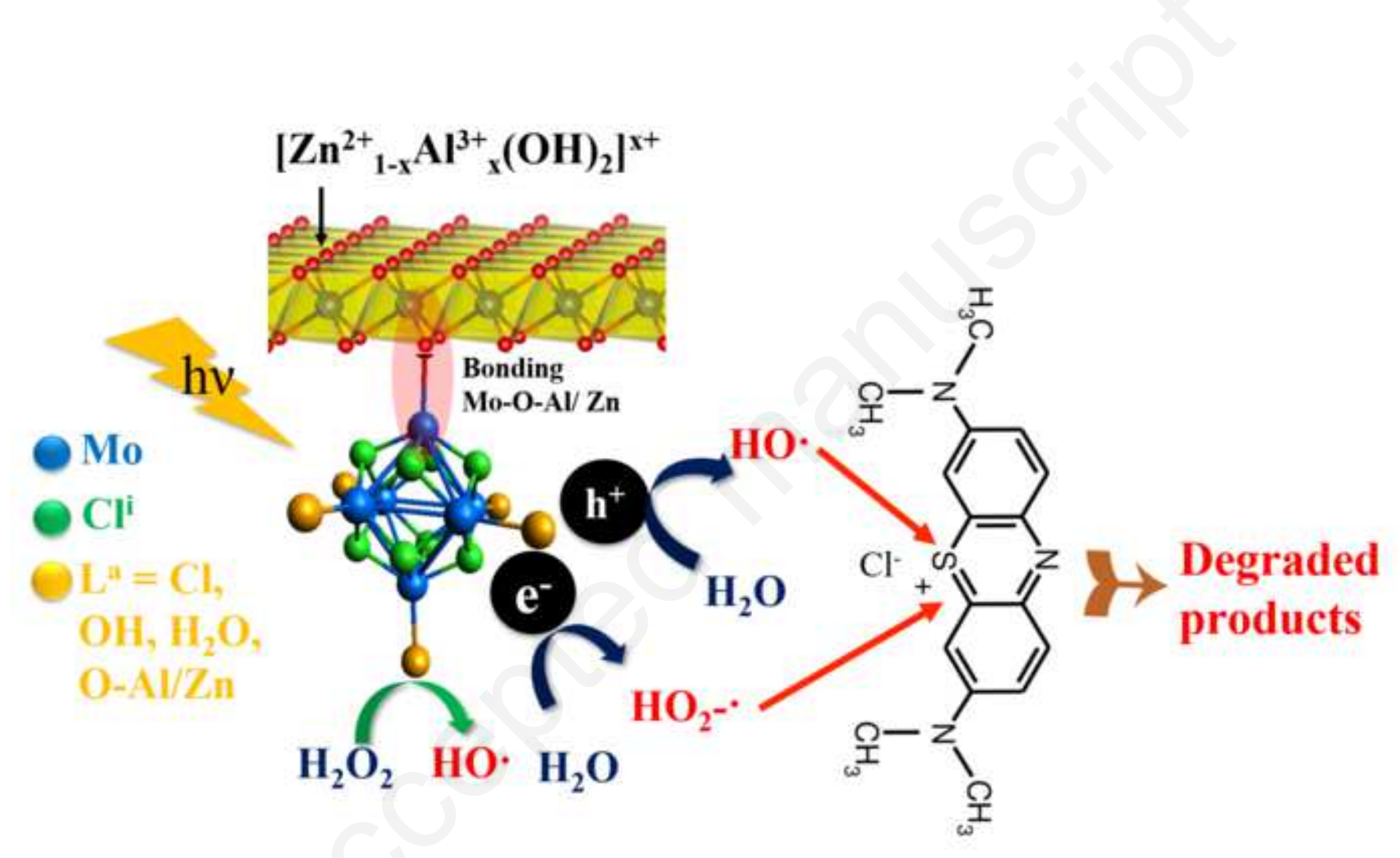

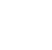

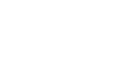
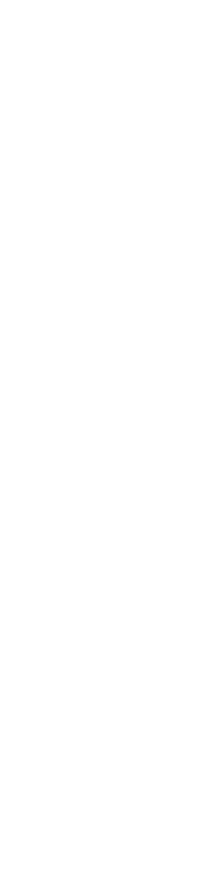

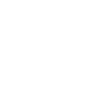

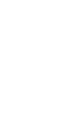

